W OR K I N G PAPER

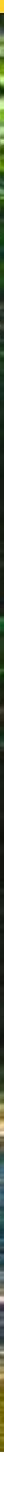

\title{
A review on compliance and impact monitoring indicators for delivery of forest ecosystem services
}

Sini Savilaakso

Erik Meijaard

Manuel R. Guariguata

Manuel Boissiere

Louis Putzel

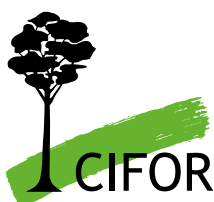





\title{
A review on compliance and impact monitoring indicators for delivery of forest ecosystem services
}

\author{
Sini Savilaakso \\ Erik Meijaard \\ Manuel R. Guariguata \\ Manuel Boissiere \\ Louis Putzel
}


Working Paper 188

๑ 2015 Center for International Forestry Research

(c) (1) Content in this publication is licensed under a Creative Commons Attribution 4.0 International (CC BY 4.0), http://creativecommons.org/licenses/by/4.0/

ISBN 978-602-387-000-4

DOI: $10.17528 /$ cifor/005640

Savilaakso S, Meijaard E, Guariguata MR, Boissiere M and Putzel L. 2015. A review on compliance and impact monitoring indicators for delivery of forest ecosystem services. Working Paper 188. Bogor, Indonesia: CIFOR.

Photo by Manuel Boissiere/CIFOR

CIFOR

JI. CIFOR, Situ Gede

Bogor Barat 16115

Indonesia

$\mathrm{T}+62(251) 8622-622$

$\mathrm{F}+62(251) 8622-100$

E cifor@cgiar.org

\section{cifor.org}

We would like to thank all donors who supported this research through their contributions to the CGIAR Fund. For a list of Fund donors please see: https://www.cgiarfund.org/FundDonors

Any views expressed in this publication are those of the authors. They do not necessarily represent the views of CIFOR, the editors, the authors' institutions, the financial sponsors or the reviewers. 


\section{Contents}

Acknowledgments $\quad$ v

Preface $\quad$ vi

Summary and recommendations vii

1 Introducing certification $\quad 1$

1.1 The basics of certification $\quad 1$

1.2 Developing certification of forest ecosystem services 2

2 Overview of monitoring 5

2.1 Monitoring compliance and impact of certification standards $\quad 5$

$\begin{array}{lll}2.2 & \text { Participatory monitoring } & 7\end{array}$

3 Assessing and monitoring the impact of certification 9

3.1 Assessing and monitoring the impact of forest management on different ecosystem services 9

3.2 Indicators for assessing the social impact of certification of ecosystem services 26

4 Monitoring compliance with certification standards 29

4.1 Existing FSC standards as a basis for compliance monitoring indicators and their relevancy for certification of ecosystem services

5 References $\quad 37$

Annexes $\quad 43$

$1 \quad$ Guidance to participatory monitoring 43

2 Guidance to measuring and other useful publications 46

Glossary 


\section{List of figures, tables and boxes}

\section{Figures}

1 Components of certification (adapted from Sprang 2001). 1

2 Monitoring systems of FSC-certified forest ecosystem services.

3 Decision tree to determine options for payments for ecosystem services (PES) and the certification of ecosystem services (ES).

4 Components of intentional management system after Mermet et al. (2005).

5 Decision tree to determine which methods are most suitable for determining a project baseline, emissions and leakage (Estrada 2011).

6 An overview of possible approaches to monitoring biodiversity (Sommerville et al. 2011).

\section{Tables}

1 Possible indicators to monitor changes in forest carbon stock. 12

2 Possible indicators to monitor the provision of water services. 17

3 Possible indicators to monitor forest condition and NTFP management. 22

4 Possible indicators to monitor social impacts of the ecosystem services scheme. 27

\section{Boxes}

1 Differences between certification and payments for ecosystem services (PES) 2

2 Monitoring effectiveness of certification

3 Six principles for operational participatory monitoring systems (Danielsen et al. 2005) 8

4 VCS step-by-step approach to carbon accounting and monitoring $\quad 10$

5 Methodology for community carbon monitoring http://communitycarbonforestry.org/ 13

6 Developing $\mathrm{H}_{2} \mathrm{O}$-equivalents 14

7 Land use and hydrological services 15

8 Rapid Hydrological Appraisal 16

9 Economic valuation of watershed services 16

10 Steps to sustainable and community-based NTFP management after Stockdale (2005) 19

11 NTFPs and timber's relative characteristics with regard to certification (Shanley et al. 2008) 20

12 Attributes of various standards and certification programs for non-timber forest products (Shanley et al.2008)

13 Biodiversity monitoring under FSC 24 


\section{Acknowledgments}

We thank Louis Verchot and Imam Basuki for their advice and Alison von Ketteler and Stefan Salvador for their comments. We also thank Judith Shaw for editing, as well as Publication team for their help in producing the report. The Government of Finland and GEF-UNEP provided financial support. Partial funding comes from the CGIAR Research Programme on 'Forests, Trees and Agroforestry: Livelihoods, Landscapes and Governance' led by the Center for International Forestry Research in partnership with Bioversity International, the International Center for Tropical Agriculture and the World Agroforestry Centre. 


\section{Preface}

'Expanding FSC certification through incorporating additional ecosystem services' is a 4-year multipartner project, funded by the Global Environment Facility (GEF). The project will test expanded Forest Stewardship Council (FSC) standards applied to emerging markets for ecosystem services in Chile, Indonesia, Nepal and Viet Nam, and will involve local and international NGOs, research institutions, private sector partners and government agencies.

The project's stated objective is 'to pilot test expanded and enhanced global and national environmental standards applied to emerging markets for biodiversity conservation and ecosystem services as an initial step for upgrading of successful models of FSC certification'. This will be achieved through establishing FSC certification as a market tool for a wide range of ecosystem services that are not fully covered in the current FSC forest management certification standards. It thereby seeks to fill a gap in the market. The pilot testing in four countries with different characteristics will demonstrate the applicability of the FSC system in practice and will enable both national and international compliance monitoring indicators to be developed. Also explicit in the project objective is a 'scaling up' to the global level via the FSC international network, as well as establishing an evidence base for the potential delivery on global environmental benefits.

A key component of the project is the development of appropriate and measurable compliance and impact monitoring indicators to be incorporated into FSC national standards in the pilot countries and into international standards. This document provides the groundwork for the development of the indicators and building monitoring programmes. It is divided into four sections: (1) introduction to certification and discussion of the implications of certification of ecosystem services for measuring and monitoring; (2) overview of different types of monitoring; (3) impact indicators and their measurement; and (4) compliance monitoring indicators in the context of existing FSC standards. 


\section{Summary and recommendations}

1. The current forest management standard of FSC has many relevant criteria for developing compliance monitoring indicators for certification of ecosystem services. It is recommended that criteria addressing social impacts and monitoring the provision of services are developed. This report provides a starting point for the development that will be continued in the coming country workshops to develop indicators.

2. The analysis suggests two potential approaches to developing ecosystem service certification under an FSC framework (Figures 2 and 3): certification of forest management (including the services provided by the forest) and certification of the forest, as well as the services. Within these approaches the complexity of a certification system ranges between two extremes: at one extreme is a simple and holistic system featuring basic performance and impact indicators for good forest management, but without the requirement to measure all individual services and co-benefit outcomes, and at the other extreme is a highly comprehensive system that deals effectively with all aspects of the complexity including measurement of forest management aspects and co-benefits, as well as the quality and quantity of forest services.

3. Accurately quantifying and qualifying ecosystem services and linking these to the quality of forest management remains scientifically and logistically challenging. Carbon appears to be the best candidate for certification (in a case where service is quantified), because there is a reasonably good understanding of the relationships between forest management and carbon emissions and carbon sequestration. Measuring co-benefits (e.g. social, environmental, biodiversity) and crucial factors such as leakage and permanence remains equally challenging.

4. In regard to water services, certification might work best if there is no 'additionality' requirement. The provision is simply linked to a well-managed forest area, and marketed as such, but there is no requirement for hard measurement or quality checks that functionally link the provision of service to forest management. This might also be the case in certification of non-timber forest products (NTFPs), i.e. the certification is based on obtaining products from an FSC-certified forest, but the production of these products is not quantitatively linked to forest management.

5. It is recommended that all ForCES projects clearly monitor their financial expenditures towards certification to inform cost-benefit analyses. Ideally, projects should dedicate some of their monitoring resources to tracking the four main threats to effectiveness of certification programmes: (1) weak standards; (2) noncompliance; (3) limited participation; and (4) adverse self-selection (the participation of projects or companies that were already certified and for which the investment required to comply with broader certification standards is limited). 



\section{Introducing certification}

\subsection{The basics of certification}

\section{In summary:}

- Socio-ecological forest systems are highly complex.

- Certification is a process of controlling particular aspects of a system to provide some guarantee that the system complies with an agreed set of rules.

Certification is a process of controlling particular aspects of a system to provide some guarantee that the system complies with an agreed set of rules. In other words, certification initiatives aim to set and implement standards and communicate these to the external world (Marx and Cupyers 2010). The principles and criteria of certification have been likened to a filter (Meidinger et al. 2003): You take a management system, pour it through a filter, check inside, and if nothing sticks, compliance with the certification criteria has been achieved. The filter is most often implemented by an independent party.
Residues in the filter indicate non-compliance and require action.

In this document, 'certification' refers to thirdparty certification, which is considered a form of independent non-state market regulation as compared to first- and second-party certification which are more akin to forms of self-regulation (Meidinger et al. 2003). In third-party certification, the first party is an individual or organization (the 'forest owner/producer') whose performance is to be assessed against the standards set by the certifier; the second party is an entity with an interest in the outcome of the assessment of the first party - and can be the buyer or any interest representation such as an industry association; and the third party is an entity with no interest commercial or otherwise in the outcome of the assessment (Figure 1). All parties are supposed to operate independently of one another (Marx and Cupyers 2010).

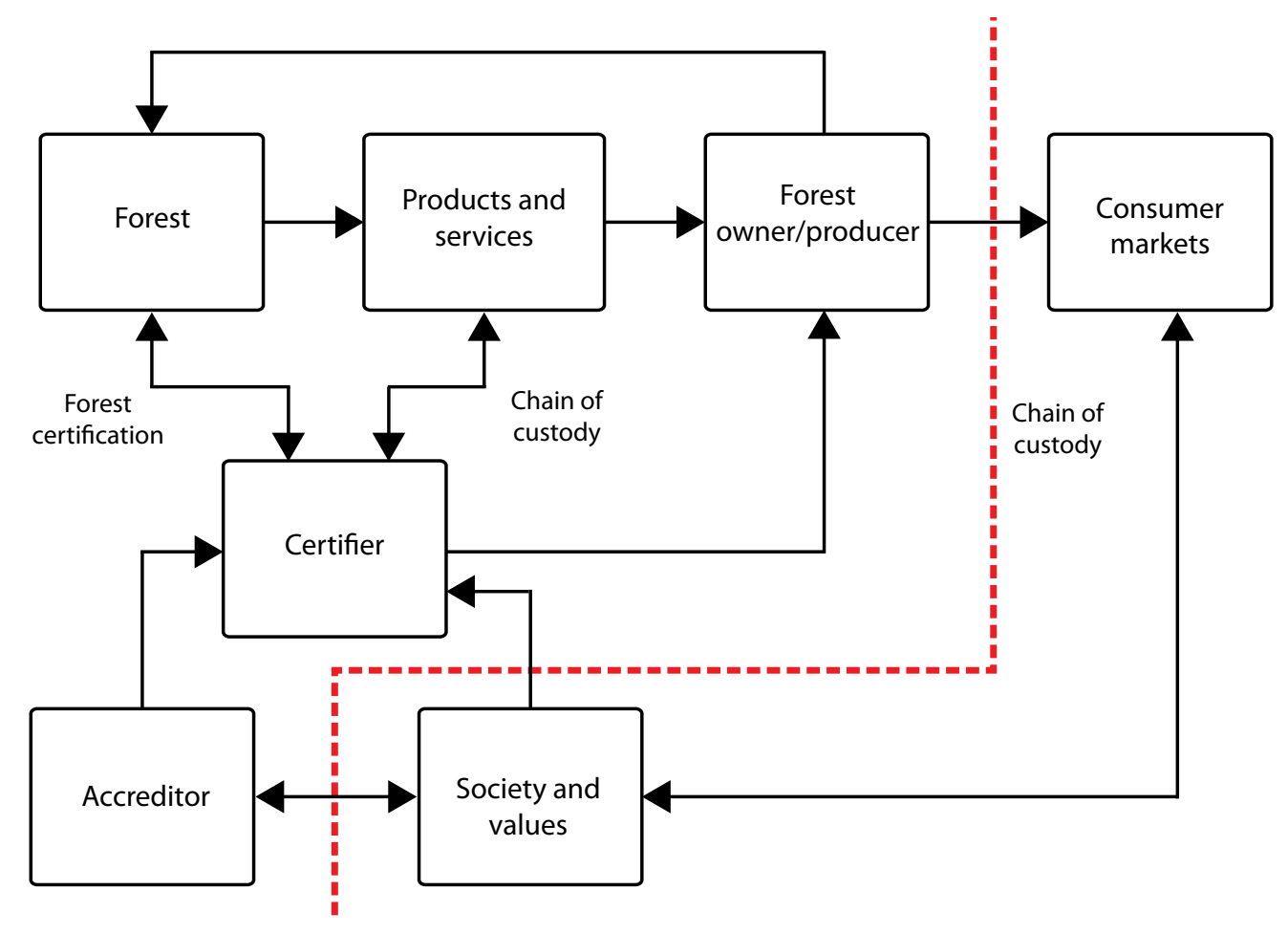

Figure 1. Components of certification (adapted from Sprang 2001). The red line emphasizes the importance of consumer markets and societal values for developing viable certification systems for ecosystem services. If a system is limited to the components to the left of the red line, then certification has limited relevance for the forests and their services. 
Forest management (FM) certification is a specific type of certification based on the application and assessment of particular management processes. Basic requirements of FM are that (1) the managers of the certified forest understand what it means to take care of a forest properly; and that (2) a person trusted by external parties and who understands proper forest management (3) visits the forest and assesses the work of the people who manage it and (4) certifies to others that things are being done correctly (Marx and Cupyers 2010). The certification of forest ecosystem services could add an additional requirement: not only should a forest be taken care of properly, but the provision of ecosystem services should somehow be related to forest management.

\subsection{Developing certification of forest ecosystem services}

\section{In summary:}

- Accurately quantifying and qualifying ecosystem services and linking these to the quality of forest management remains scientifically and logistically challenging.

- Some services could be bundled with general assessments of forest management quality. Other services do require a quantified link between service provision and forest management (e.g. avoided carbon emissions through improved forest management).
- Development of certification systems for forest ecosystem services needs to consider the trade-offs between a comprehensive and detailed approach that is expensive and time consuming and a more holistic approach that provides less detail on management, services and co-benefits but is easier and cheaper to implement.

Putting the science in place to link service provision to the quality of forest management is very challenging. One of the major challenges is the need to quantify and commoditize ecosystem services for trading purposes as well as for monitoring and verification (Guarigauta and Balvanera 2009; Meijaard et al. 2011). This may be relatively straightforward for goods such as forest honey or shade-grown coffee (Figure 2), but potentially complex for services such as water purification, pollination, flood or disaster risk reduction, or carbon sequestration. If these intangible services are sold to buyers, their tradable quantities will likely depend on the quality of forest management. For example, a certain amount of forest carbon can be traded if the forest owner can demonstrate that its reduced-impact logging (RIL) management has prevented the emission of carbon compared to the baseline (Figure 2). Measuring these intangible services remains difficult: only for carbon is there sufficient scientific insight to link forest management with amounts of carbon stored and sequestered, thus providing a tradable value (Meijaard et al. 2011).

\section{Box 1. Differences between certification and payments for ecosystem services (PES)}

Although both certification and PES are market-based instruments and a working PES scheme is needed for certification of ecosystem services, there are key differences between them.

1. Certification needs multiple buyers or outside interest in regard to the outcome of the ecosystem service scheme, whereas PES can be set up in a one buyer-one seller system.

2. Whereas certification is a market-oriented governance tool (i.e. preset criteria need to be fulfilled) to ensure good forest management and requires third-party verification, PES is a financial tool and does not necessarily require third-party verification as long as both parties are satisfied that contract obligations have been met (i.e. trust may be enough).

3. Certification criteria are the same for all although differences between countries may exist, whereas in PES the contract obligations can differ among different PES schemes and also within countries.

4. Certification should be a way to show that management practices maintain or enhance the provision of services, whereas PES agreements can basically set a price without relation to trade volumes of service/good as long as both the buyer and the seller are satisfied with agreed conditions.

5. In PES, payments do not necessarily have to be financial. Instead, compensation can be in non-cash benefits, e.g. land rights. In certification, compensation is usually financial, e.g. in the form of price premiums or access to new markets.

6. Certification is likely to have higher costs due to the verification requirement. 


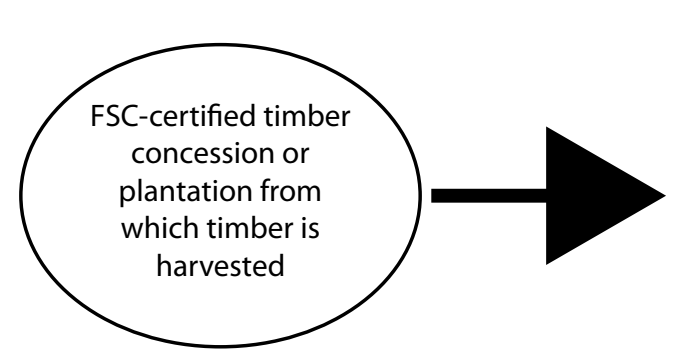

Market buys FSC-certified timber knowing that it comes from a well-managed concession. Trade volumes and premium prices are not based on additionality. Link between forest management and timber volume does not need to be established.

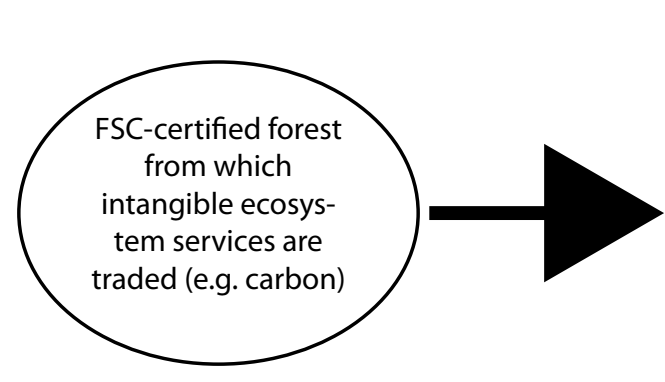

Market buys FSC-certified ecosystem services knowing these came from a well-managed concession. Trade volumes and prices are based on additionality; i.e. the additional quantity or quality of ecosystem services that can be traded because of better forest management. This requires quantification of ecosystem services and its correlation with the quality of forest management.

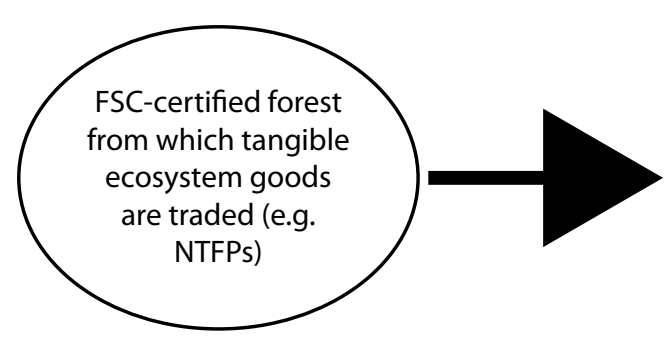

Market buys FSC-certified goods knowing these came from a well-managed forest. Trade volumes and premium prices are not based on additionality. Link between forest management and trade volume does not need to be established.

Figure 2. Monitoring systems of FSC-certified forest ecosystem services. The choice of system will depend on how services are traded on markets and whether their trade requires quantification of the link between forest management and service quantity and quality.

Certification of ecosystem services might not necessarily require their quantification (Figures 2 and 3). Buyers of forest products and services might happily pay the premium price of certification based on the knowledge that the system from which these products and services were derived was well or 'sustainably' managed. So a certifier could declare that a particular forest was well managed, and that therefore, for example, the honey from that forest was automatically certified and could thus be sold as such. But, as explained above, services such as water or carbon may need a quantified link between the type of forest management and the service amounts that can be traded from a forest. The bundling of services might overcome this problem to a certain extent, but several studies have highlighted the tradeoffs between different services while functional links between different forest services and goods remain poorly understood (Wendland et al. 2010). It is also worth keeping in mind that bundling or stacking of services will not work in all areas as not all areas are equal in providing multiple services. It is possible that other services are not present, e.g. a watershed may be important for its water service but may not have high carbon stock or value as a tourism destination, or a service may be present but at lower levels than in some other ecosystem, e.g. peatlands in Indonesia are important for carbon but support less than half of the plant diversity of forests on mineral soil (Paoli et al. 2010). In the latter case, there is a risk that payment to preserve less biodiversity-rich ecosystems for carbon may lead to increased pressure to convert more biodiversity-rich forests to other land uses.

There is an increasingly common demand from markets that certification also consider other objectives of forest management, such as community development and rights. A certification system for forest ecosystem services, therefore, needs to establish a quality measure for forest management and how this affects traded ecosystem services and other forest beneficiaries. This requirement becomes complex 


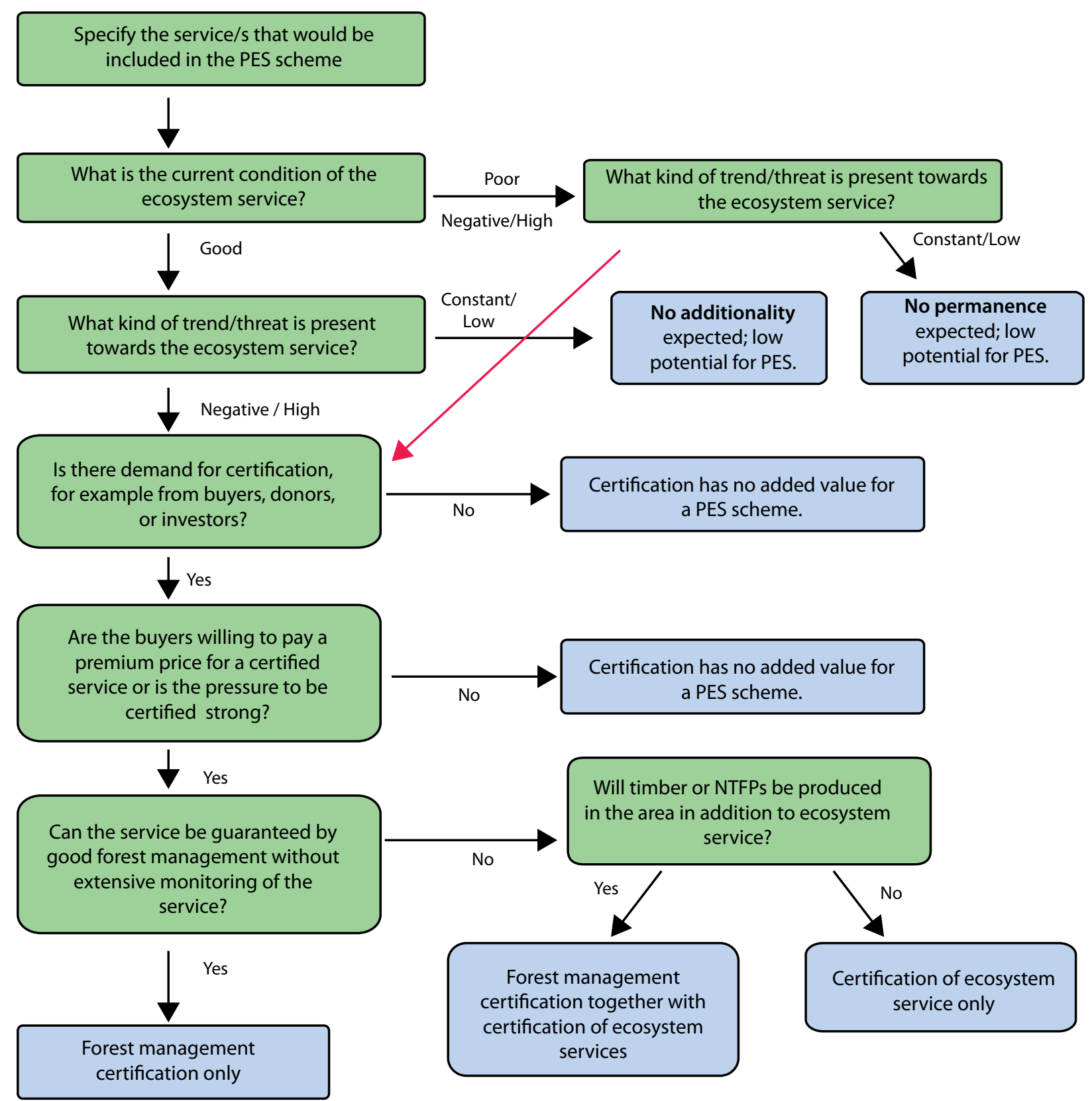

Figure 3. Decision tree to determine options for payments for ecosystem services (PES) and the certification of ecosystem services (ES).

(Vogt et al. 2000). Systems of forests, their services and goods and their co-beneficiaries are also highly complex. Managing such systems requires addressing many of the factors that influence system outcomes: forestry economics, environmental links between forest and services, land rights, local, national and international politics; poverty, resource use, economic development, markets, culture, etc.

How could any system capture this complexity and develop standards that guarantee a certain level of minimal performance in all targeted outcomes? One possibility is to develop a highly comprehensive certification system that deals effectively with all aspects of the complexity. It would need to measure forest management aspects, as well as the quality and quantity of forest services; it must also determine measures for co-benefits. Such a system would be expensive to implement and time consuming. An alternative would be to adopt a simple and holistic approach featuring basic performance and impact indicators for good forest management, but without the requirement to measure all individual services and co-benefit outcomes. 


\section{Overview of monitoring}

\subsection{Monitoring compliance and impact of certification standards}

\section{In summary:}

- Monitoring needs to assess implementation of standards and then verify whether results achieve overall sustainability objectives.

- Monitoring needs to consider quality and quantity of forest goods and services.

- Selection of indicators for monitoring should consider effectiveness, scientific relevance and costs.

- Opportunity costs of avoided deforestation need to be monitored.

Monitoring and verification are key aspects of certification that should ensure that certified forests keep fulfilling the agreed principles and criteria (Nussbaum 2005). Monitoring provides evidence to buyers that certified goods and services are indeed obtained from forests managed according to agreed standards. Also, monitoring assists forest managers in the adaptive management of their area, helping them to assess whether certain strategies are effective and efficient. Finally, monitoring is required if goods and services obtained from or maintained by certified forests are quantified. Many forest managers recognize the need to monitor, but are unclear what to measure and how to measure it.

In an ideal world, there would be a perfect understanding of how different management interventions affect forest functioning and services, and this understanding could be used to dictate a clear code of practice. Management compliance could be obtained simply by monitoring the implementation of management activities, e.g. did the forest manager extract timber according to internationally recognized best practices?

Unfortunately, the link between forest management and the maintenance of certain environmental and social standards is not straightforward (Meijaard et al. 2011). Often we simply do not know how a certain type of forest management affects forests and their services. For example, how much timber from a particular watershed could be extracted without significantly affecting its water storage capacity?
Answers to such questions are rarely known, and if they are, they likely pertain to a specific area only and cannot be generally applied. However, in the absence of clear understanding of the impact of management actions, careful forest management that guarantees the permanence of supplied ecosystem services could be sufficient.

Certification tries to ensure good forest management by splitting the monitoring process into two:

- Compliance monitoring (i.e. implementation monitoring) - this checks whether a minimum level of performance is implemented on the ground. The minimum level is determined by the standard and is communicated in the form of compliance monitoring indicators. Thus, the purpose of compliance monitoring indicators is to prevent, minimize or mitigate negative environmental and social impacts of forest management.

- Impact monitoring (i.e. effectiveness monitoring)

- this evaluates the impact of existing management practices. It gives information on whether the standards are adequate and how they can be further refined to ensure continued progress towards long-term sustainability goals.

Within the context of FSC, most information about the impact of certification is generated through audits of forest management units, primarily through the analysis of Corrective Action Requests (CAR) (FSC 2009). This is an indirect method to evaluate the effects of certification processes, based on evaluations done by certification bodies. Audits are, however, confidential in detail, and may not actually provide much information about the long-term social and environmental sustainability of the system. Such CAR-based monitoring is focused on progress towards sustainable forest management but cannot determine the actual impact on ultimate social and environmental goals, unless supported by more detailed monitoring processes.

In regard to ecosystem services, an additional type of impact monitoring may be required to facilitate their trade: this is the actual measurement of the services provided by the forest in order to translate these into a market price. The measurement of services provides 
means to try to establish knowledge on how a certain type of forest management affects forests and their services.

In the context of ecosystem services the key criteria to address in monitoring are:

- Additionality (actual or prevented changes in quality and quantity of ecosystem services compared to a business-as-usual scenario).
- Baseline/reference level (payments for services are based on a baseline).

- Leakage/displacement (extent to which payment for ecosystem services would displace detrimental activities to other locations).

- Permanence (how to make sure that services are maintained permanently).

One of the key aspects of monitoring is repetition. In order to capture changes due to or in forest

\section{Box 2. Monitoring effectiveness of certification}

A recent study on GEF eco-certification (Blackman and Rivera 2010) suggested that projects should dedicate some of their monitoring resources to tracking the four main threats to effectiveness of certification programmes: (1) weak standards, (2) non-compliance, (3) limited participation, and (4) adverse self-selection (the participation of projects or companies that were already certified and for which the investment required to broader certification standards is limited). Measuring the effectiveness of certification is not the main objective of the ForCES study. However, to inform FSC about the best way to develop new criteria and indicators for ecosystem service certification it would be highly useful to understand under which circumstances certification is most likely to work. In that respect, it is interesting to note that several ForCES pilot sites were already FSCcertified prior to the selections for ForCES. Obviously, this makes it easier to develop and test new certification approaches based on existing FSC ones, but the effectiveness of these approaches may not be representative for project implementation in sites that had no prior FSC certification.

To better understand the effectiveness of different approaches to certification, especially from a cost perspective, it would be very useful if each project kept detailed records of all project expenditures (including staff time) and external assistance (e.g. when advisors from elsewhere in an organization come to help the project). The same type of accounting would ideally be done for the other main project partners, such as the landowners who implement measures to comply with new standards. Because transaction costs are one of the key determining factors for the viability of certification programmes, it will be very important that all ForCES pilot site teams keep track of all expenditures towards certification in their sites. It is important to start this very early on because about half of forest certification costs occur in the first year of the project (Simula et al. 2004).

With high transaction costs being one of the main limitations to successful scaling up of certification programmes, a better understanding of how to reduce these costs and keep them as low as possible without sacrificing programmatic integrity is crucial. This pilot phase with 11 different pilot sites provides an ideal test ground to understand the implications of costs for the project. After all, these pilots should not simply be trying to generate environmental benefits at the project site; they should also attempt to catalyze the mainstreaming of biodiversity globally though the generation of credible evidence about what works and under what conditions.

Data to be collected with regard to understanding certification effectiveness include information on any key factor that affects outcomes to be measured, e.g. local demand for firewood in relation to the targeted objective to maintain forest cover. To establish a counterfactual against which certification outcomes can be measured, certification programmes should ideally collect outcome data for both participants and non-participants, and from before and after certification is assigned. Collecting data from participants is generally straightforward and low cost. More difficult - but critically important - is collecting data from non-participants and baseline data from both participants and non-participants. Collecting data from a comparison group of non-participants makes it easier to eliminate rival explanations for changes in impact indicators, such as movements in commodity or input prices affecting all producers. Selecting a comparison group can be difficult and might work best where many potential project participants could be certified (e.g. local farmers in a multi-use watershed). A lottery-type selection of who qualifies first for certification would provide a random sample of certified versus non-certified participants from essentially the same sample. 
management, a simple assessment is not enough. Instead, repeated measurements or assessments are needed to ensure continuous good forest management. Determining the best approaches to monitoring also depends on how much is actually known about a site and its services. Based on case studies in the Philippines, a multi-tiered system was proposed for classifying forest Payments for Ecosystem Services (PES) projects on the basis of how much was known about them (Lasco et al. 2008):

- Tier 1 - payments are based on established ecological principles and local knowledge.

- Tier 2 - in addition to the above, payments are based on simulation modelling and limited site information.

- Tier 3 - in addition to above, payments are based on site-specific quantitative measurements of environmental services.

Monitoring costs increase from tier 1 to 3 , and this becomes an important consideration when deciding the type of monitoring that FSC-based ecosystem services certification should demand.

\subsection{Participatory monitoring}

In the case of ecosystem service schemes that directly involve rural communities, the development of locally relevant monitoring protocols is potentially critical for enhancing adoption and generating trust among providers and beneficiaries. Traditionally, monitoring programmes have been set up and run by professionals and have had few links to local communities; this is relatively costly and usually ends when the project finishes (Danielsen et al. 2005). During the past decade, increasing emphasis has been placed on participatory approaches and locally relevant monitoring schemes (Becker et al. 2005; Danielsen et al. 2007; Gomani et al. 2010). By involving local communities, monitoring can be sustained over time, costs can be kept down and decisionmaking can be brought closer to the communities. Further, local involvement in the design and implementation of a monitoring scheme raises environmental awareness and offers possibilities to build trust between different stakeholders and enact together in response to changes (Becker et al. 2005; Poulsen and Luanglath 2005). Locally based monitoring is particularly relevant where communities act as sellers of ecosystem services.

Danielsen et al. (2009) defined five types of involvement of local people in monitoring schemes:

1. No involvement at all. Monitoring is done by and for professional scientists.

2. Externally driven monitoring scheme with local data collectors. In this scheme, local people participate only in data collection but professional researchers handle all the other activities, as well as design, analysis and interpretation of the results.

3. Collaborative monitoring with external data interpretation. This scheme involves local people in data collection and decision making, but the design of the scheme, data analysis and interpretation are done externally.

4. Collaborative monitoring with local data interpretation. In this scheme, local people participate in data collection, analysis or interpretation, as well as decision making about the management of the resources. Scientists provide advice and training.

5. Autonomous local monitoring. Many customary systems of natural resource management in developing countries belong to this category (without being explicitly called monitoring) as local people carry out the whole monitoring process without direct involvement of external agencies.

Which type will be the most appropriate depends on the objectives of the monitoring programme and conditions of the site (e.g. whether the forest is privately or community-owned and/or managed).

For a participatory monitoring system to be successful it needs to be simple and locally appropriate. Danielsen et al. (2005) identify six principles for the sustainability of a monitoring system (Box 3). In addition, as much as possible, it is important to use equipment that can be maintained locally and to build capacities of those involved in monitoring. Preferably, local people should be involved as much as possible in the design phase of the monitoring system to increase ownership of the scheme.

It is important to note that participatory monitoring and participatory resource management are two different things. Although local people may collect 


\section{Box 3. Six principles for operational participatory monitoring systems (Danielsen et al. 2005)}

1. Addresses goods and services which the community derives from ecosystems being monitored.

2. Ensures benefits to local people involved in monitoring exceed the costs. This is especially important if monitoring interferes with people's daily activities.

3. Ensures that conflicts and politics between government managers and communities do not constrain the involvement of local stakeholders in the process.

4. Builds on existing traditional institutions and other management structures as much as possible.

5. Institutionalizes the work at different levels of governance - from the relevant policies of the country to the officers involved in implementing the system.

6. Stores, analyzes and ensures data are accessible locally.

Note: Garcia et al. (2004) point out the monitoring system may not work when the necessity of better governance clashes with traditional, undemocratic processes.

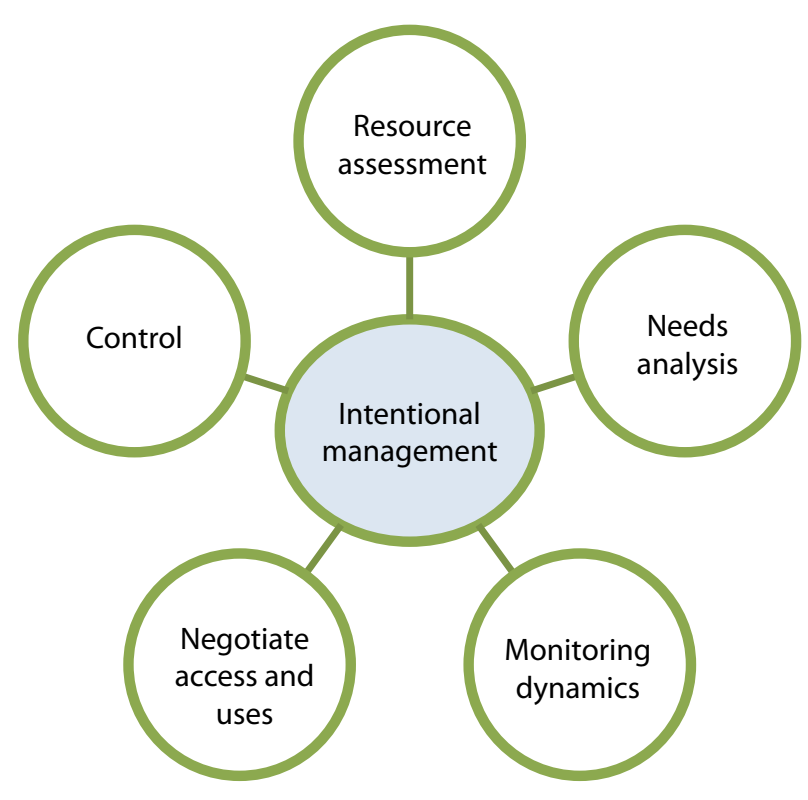

Figure 4. Components of intentional management system after Mermet et al (2005). information about the state of their environment, they may not have the power to make or influence management decisions (Garcia and Lescuyer 2008). In such a situation, the collected information may benefit the local population. However, as the critical link between monitoring and decision making is missing, it should not come as a surprise that eventually the monitoring system may be put aside, especially if costs outweigh benefits for the local people. For a resource to be managed in a truly participatory way, local people should have a significant share of authority, responsibility, duties, benefits and management capacity. Mermet et al. (2005) introduced the term 'intentional management' for a management system based on shared and clear objectives. It can be divided into five components (Figure 4), which are all equally important (Garcia 2008). If local people are directly involved in all five components, local monitoring system becomes legitimate, effective and sustainable. Otherwise, the chances are that participatory monitoring will fail in the short term. 


\section{Assessing and monitoring the impact of certification}

\subsection{Assessing and monitoring the impact of forest management on different ecosystem services}

In summary:

- There are several possible indicators to monitor the provision of ecosystem services each with different advantages and disadvantages.

- Certification of carbon sequestration has the most potential to succeed.

- Communities can be involved in monitoring through participatory monitoring methods.

It will be important that certification leads to forest management that maintains or enhances the provision of services. As mentioned earlier this may not require quantification of the service produced but for trading purposes the provision of service may need to be measured. Hence, in this section we discuss the measurement of services and provide potential indicators that are either directly or indirectly linked to the provision of services. Sources for further guidance can be found in Annexes I and II.

\subsubsection{Carbon}

Among non-timber ecosystem services and goods, certification of carbon sequestration appears most likely to succeed. Unlike other services, carbon meets some of the preconditions and advantages for certification: there are potential markets with multiple agents. As a commodity, carbon can be measured as well as perceived. It can be sequestered, stored, quantified and compared among many different places where carbon is either produced or stored. Carbon thus fulfils many criteria of commoditisation. The science to measure carbon is also much more mature and less complex than for watershed services or other even less-tangible ecosystem services (Meijaard et al. 2011).

\section{American Carbon Registry Standard \\ Summary: ACR is a voluntary carbon offset programme that publishes standards, methodologies, protocols and tools for GHG accounting and maintains a registry for the purchase and sale of offsets.}

Scope: US. Forestation projects.

\section{CarbonFix Standard}

Summary: The Standard was founded to promote the potential of forest carbon projects and increase the prevalence of sustainably managed forests worldwide.

Scope: Global. Forestation projects.

\section{Climate Action Reserve Standard}

Summary: CAR provides a set of rigorous protocols, guidelines and tools to support the North American carbon market.

Scope: US. Reforestation, IFM and/or avoided deforestation projects.

\section{Climate, Community and Biodiversity Standard}

Summary: A project design standard for evaluation of land-based carbon mitigation projects in the early stages of development. The CCB Standard identifies projects that simultaneously generate climate, biodiversity and sustainable-development benefits. Carbon credits are not issued under this standard.

Scope: Global.

\section{Plan Vivo Standards}

Summary: Plan Vivo offers a system for managing the supply of verifiable emission reductions from rural communities in a way that promotes sustainable livelihoods.

Scope: Global. All land-based project types.

\section{Verified Carbon Standard}

Summary: A robust, global standard for approval of verified offsets, which are issued as Verified Carbon Units (VCUs) and transacted through a registry platform.

Scope: Global. All land-based project types. 


\section{Box 4. VCS step-by-step approach to carbon accounting and monitoring}

VCS offers a number of specific methodologies, each of which refers to a particular forest carbon context (see Annex I). Details between these methods differ but they all have a similar step-by-step approach to carbon accounting and monitoring:

- STEP 1 - Definition of project boundaries and scope

- STEP 2 - Selection of baseline, additionality and baseline modelling

- STEP 3 - Baseline scenario greenhouse gas emissions (e.g. for improved forest management, this would include calculation of carbon stocks in commercial timber volumes, dead wood generated in the process of timber harvest, carbon sequestered in wood products and change in carbon stocks due to forest regrowth after harvest)

- STEP 4 - Project scenario net greenhouse gas Emissions (for improved forest management, this would involve assessing ongoing forest growth and forest disturbance in the project scenario)

- STEP 5 - Project leakage

- STEP 6 - Net project greenhouse gas emission reductions

- STEP 7 - Project verified carbon units

- STEP 8 - Project monitoring

A range of standards for carbon-forest carbon offsets are in use. These include, among others, the Clean Development Mechanism (CDM), the Greenhouse Friendly Initiative in Australia, ISO 14064 (which is a carbon project accounting standard), Société Générale de Surveillance (SGS), Carbon Offset Verification Standard, Social Carbon, and the Verified (formerly 'Voluntary') Carbon Standard (VCS). Of these, the VCS appears to be most logical framework for FSC carbon certification because its emission-trading scheme has good access to markets. CDM standards are another possibility, but will not include natural forests in the foreseeable future. The Mapanda and Uchindele project in Tanzania, which aims to reforest 10,800 ha of degraded grassland with pine and eucalyptus for carbon sequestration and sustainable harvest, is an example of a joint FSC and VCS project (as well as CCB) (Green Resources 2010).

The value and demand of carbon credits is related to the standard under which the project is developed. A survey of potential buyers of carbon credits identified the CDM and VCS as the most desirable standards (De Gryze and Durschinger 2009; Ecosecurities 2009). Credits generated from projects that are only registered by the Climate, Community and Biodiversity Alliance (CCBA) standard are less desirable. However, a dual certification of CCBA combined with either CDM or VCS can provide carbon buyers more certainty around co-benefits; this makes forest carbon projects more interesting for a certain segment of the carbon-credit buyers and reward communities for the multiple ecosystem services they manage. The choice of a standard should not only depend on the price or demand for credits under that standard, but should also be based on the level of effort, costs and time required to validate the project under the registry.

Three main forest-carbon project types are relevant in the ForCES context (Ridoutt and Pfister 2010):

- Afforestation and reforestation (A/R and ARR) involves the planting of trees or silvicultural activities that promote natural regeneration on degraded woodlands through thinning, removal of exotic species or coppicing. Under the VCS, this is called 'afforestation, reforestation and revegetation (ARR)', and includes the regeneration of degraded forests and revegetation with non-tree species (De Gryze and Durschinger 2009). CDM and Climate, Community and Biodiversity Alliance use the term 'Afforestation/Reforestation (A/R)' (Law in press).

- Avoided deforestation or forest degradation (REDD) refers to the avoidance of the conversion of forest land to non-forest land, or the avoidance of the gradual decrease in forest biomass through forest degradation.

- Improved Forest Management (IFM) involves the altering of forest management to increase the standing biomass of a forest (reducing timber harvest, stopping timber harvest, increasing rotation cycles, etc.).

De Gryze and Durschinger (2009) clarify that each of the three project types has different requirements ('eligibility criteria'), as well as different 


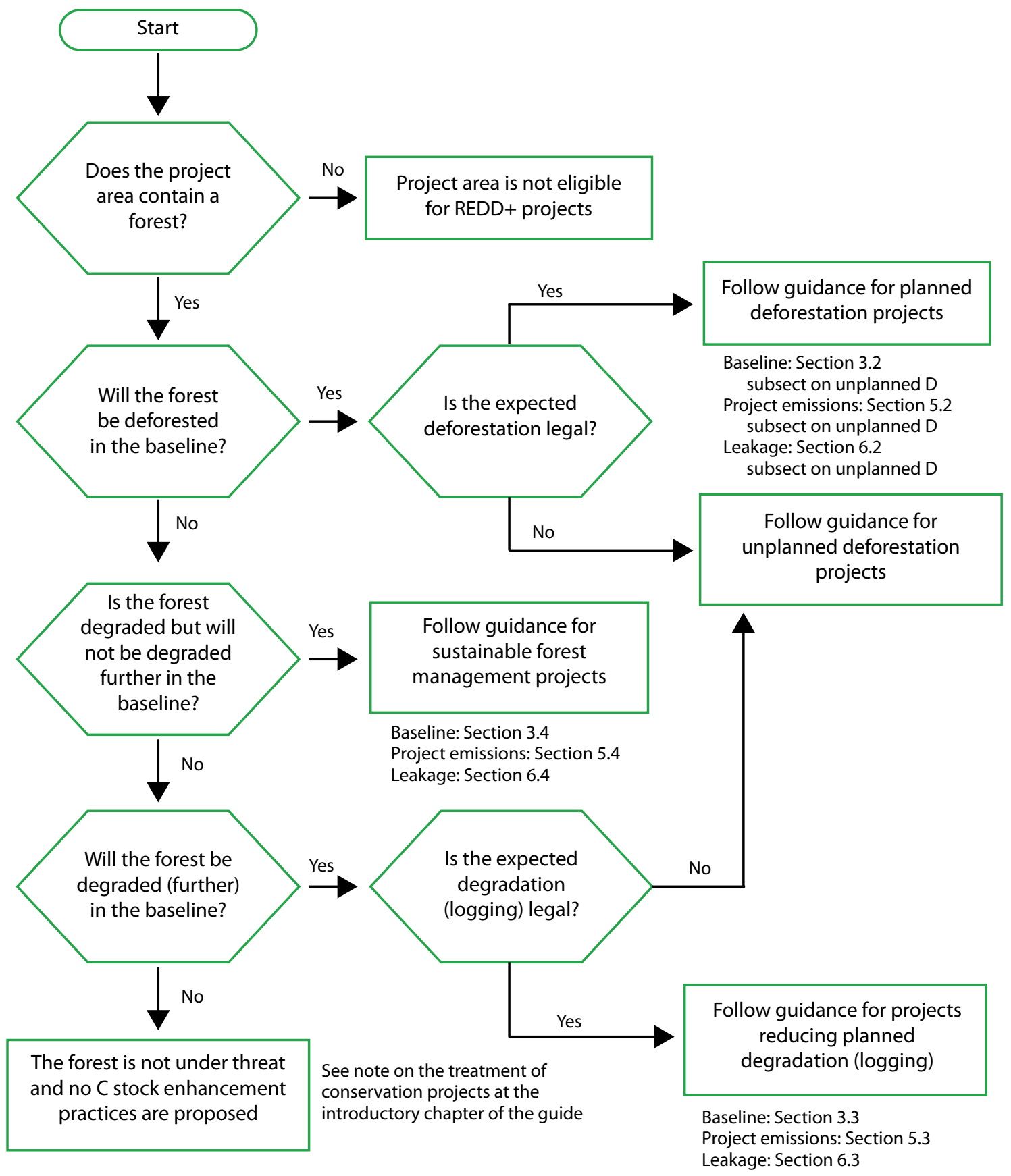

Figure 5. Decision tree to determine which methods are most suitable for determining a project baseline, emissions and leakage (Estrada 2011). The section numbers for baseline, project emissions, and leakage refer to the guide.

methodologies to calculate the volume of carbon credits generated by a project (Figure 5). The requirements and methodologies are developed by carbon standards.

Emissions from deforestation and degradation can be estimated from two important variables: areal extent of deforestation and degradation; and carbon stock densities per area (Wertz-Kanounnikoff 2008). Measuring forest carbon thus involves keeping track of a large variety of factors related to the above variables. This includes, for example, aboveground biomass, coarse woody debris, litterfall, vegetation height, dead-wood decomposition, leaf area index, soil carbon, specific gravity by tree species, percentage of canopy cover and more. Much carbon accounting focuses on the aboveground biomass in trees and shrubs, but Bird et al. (2010) highlighted the need to include dead wood and litter in estimated emissions, particularly when estimating emissions from deforestation. Wertz-Kanounnikoff (2008) observed that current remote sensing methods are useful, 
Table 1. Possible indicators to monitor changes in forest carbon stock.

\begin{tabular}{ll}
\hline Possible indicators & Advantages and disadvantages \\
\hline Changes in forest area & \\
\hline Area of prevented deforestation & $\begin{array}{l}\text { Easy to monitor by remote sensing or by systematic forest } \\
\text { inventories. } \\
\text { - Both types of monitoring can be costly; tells nothing about the } \\
\text { condition of the forest. } \\
\text { Afforested or reforested area }\end{array}$ \\
& + Easy to monitor. \\
\hline
\end{tabular}

Changes in carbon density of the area

Avoided degradation through management actions

Sustainable harvest levels

Preventing fire

Sustainable harvesting practices

Preventing illegal harvesting

Area of restored and rehabilitated forest

Area of restored and rehabilitated forest

+ Rather easy to monitor once the level for sustainable harvesting is known; direct relationship with forest condition.

- Difficult to estimate sustainability threshold; harvesting levels may not be honestly reported.

+ Easy to verify whether action have been taken to prevent fire.

+ Information about the harvesting practices easy to get from management plans and/or by interviewing people. Has a direct relationship to forest condition.

- Ground truthing needed to verify information, which can be costly.

+ Easy to see whether action have been taken to prevent illegal harvesting.

- Can be expensive.

+ Easy to monitor by remote sensing or by systematic forest inventories.

- Both types of monitoring can be costly; area tells nothing about the condition of the forest.

\section{Quantity of carbon}

Aboveground biomass

- Standing vegetation, e.g. the number of trees and their volume, vegetation height, leaf area index, \% canopy cover

- Dead wood, litter, and dead wood decomposition

- Coarse woody debris

- Litterfall

Belowground biomass

Soil carbon
+ Relatively easy indicator to understand; most of the variables easy to measure; methods to measure standing vegetation well established.

- Measuring can be slow and costly, especially when the number of measured variables increases.

+ Increases accuracy of the carbon pool estimate; a conservative shoot-root ratio can be used without measurement.

- Time consuming and relatively expensive to measure; no standardized techniques exist.

+ Well established methods to measure; increases accuracy of the carbon pool estimate.

- Laboratory analysis may be expensive. especially for deforestation monitoring; the study also noted potential for future satellite-based carbon stock monitoring, but stressed ground-based measurements remain important, principally to monitor carbon stocks, but also to verify results obtained from image interpretation for deforestation and degradation mapping. Still, mapping carbon stocks over large areas without satellite data is clearly problematic (Goetz 2009). With regard to any ForCES pilot sites that want to assess the potential of carbon 


\section{Box 5. Methodology for community carbon monitoring http://communitycarbonforestry.org/}

The following participatory carbon monitoring methodology (Verplanke and Zahabu 2009; Subedi et al. 2010) assumes that intermediaries (e.g. local forest department or NGO) with basic computer skills are available, can train people from the community and maintain the equipment.

Step 1. Boundary mapping. High-resolution satellite images, if available, printed on a large scale can be used to find the different land cover and natural boundaries and to trace individual forest blocks easily. Forest boundaries are mapped by walking if satellite images are not available or for areas where the natural boundary cannot be observed clearly. A handheld computer or personal digital assistant (PDA) linked to a global positioning system with a standard geographic information system (GIS) programme and a georeferenced base map or satellite image is used. The forest area is automatically calculated.

Step 2. Identifying strata. Strata are areas distinct from each other in forest types, density and species. As such, they will have different amounts of carbon stored. Forests are stratified on the basis of forest type, dominant tree species, stocking density, age and aspect (slopes, orientation), as well as by different types of community management. Strata boundaries are added to the base map using the same technique as for boundary mapping (walking the boundaries of each stratum).

Step 3. Pilot survey: determining the number of permanent sample plots and estimating variance. Around 10-15 circular pilot plots are randomly set out in each stratum. The central point is marked and a sampling circle is set out. The plot size is dependent on tree density: the higher the density, the smaller the plot (MacDicken 1997). Data on dbh (diameter at breast height) and the heights of all trees over $5 \mathrm{~cm} d b h$ within the circle are recorded in the database of the PDA or a datasheet. Trees are identified using local terminology. Local allometric equations and expansion factors are used to convert $\mathrm{dbh}$ and height variables into biomass estimates. Variance in biomass in pilot survey plots is used to calculate the sample size needed to achieve a maximum of $10 \%$ error.

Step 4. Laying out permanent plots. The number of permanent sample plots is dependent on the size and types of forest stratum. Plots used must be the same size as those used in the pilot survey. Central points are marked in the field and on the computer base map using parallel transects across the area from a random start point. The following variables are measured: above-ground tree and sapling biomass, below-ground biomass, soil organic carbon, leaf litter, herbs and grass, dead wood and fallen stumps. To measure the leaf litter and herb layers, $1 \mathrm{~m}^{2}$ quadrants or circular subplots within the permanent plots are used. The samples are bagged, dried and weighed.

Step 5. Re-finding the permanent plots and measuring biomass in each of them. For the annual survey by the community team, the plots are located using the GPS. The inventory is carried out as described in Step 3.

Step 6. Data analysis. After the data collection is completed, data analysis of various carbon pools measured in the forests is conducted.

trade for PES certification, a mixed approach of remote sensing and on-the-ground carbon stock assessments is therefore recommended. Table 1 lists possible direct and indirect indicators to monitor changes in forest carbon stock.

\subsubsection{Water services from forests}

Forests can provide four main types of watershed services: (1) increase water quality by keeping nutrient and chemical contaminant levels low; (2) regulate surface and groundwater flows; (3) increase base flows during the dry season and hence improve water supply; and (4) improve or maintain aquatic productivity (Johnson et al. 2001). However, the relationships between forests and water are complex and the impact of forests on the watershed services will depend on a number of site-specific factors such as climate, terrain and soil composition (Box 7).

Meijaard et al. (2011) suggest the complexity of the relationship between forest management and services that can be rendered from watersheds is one reason 


\section{Box 6. Developing $\mathrm{H}_{2} \mathrm{O}$-equivalents}

$\mathrm{CO}_{2}$ is commonly traded under a single figure in the units of carbon dioxide equivalents $\left(\mathrm{CO}_{2}-\mathrm{e}\right)$ anywhere in the world and under whatever circumstances it is sequestered or emitted. Conversely, the value of water varies highly across the globe depending on its scarcity, use, cleanliness, etc. New thinking is now emerging on how to develop an equivalent unit of water, $\mathrm{H}_{2} \mathrm{O}$-e, which would allow these units to be certified and traded irrespective of origin (Ridoutt and Pfister 2010). Using equivalent units of water enables meaningful comparison both between different products and between different stages of a particular product's life cycle. The concept recognizes that water is used from a range of different sources, with different levels of scarcity and different environmental impacts: irrigation water withdrawn from ground- or surface-water (blue water), rainwater (green water) and the volume of polluted water related to the use of fertilizers in crop production (grey water) (Chapagain and Hoekstra 2011). While this line of thinking is important if global trade in certified water retention or production is envisaged, significant methodological challenges remain for developing land use-specific $\mathrm{H}_{2} \mathrm{O}$-e. Even if no agricultural water-uses were included under the certification scheme, the system would still require that we understand the specific hydrological functioning of, for example, a semi-deciduous forest on Lombok and know how this differs in terms of water production from a temperate rainforest in Chile (Levia et al. 2011). Unless these differences are clear, global trade in certified water equivalents remains impossible, and certification and water trade would have to be limited to local systems in which consumers and producers agree on a water price.

why certification of such services remains technically challenging (Box 6). Furthermore, it takes time to acquire thorough knowledge of the hydrodynamic properties of a water body. It is difficult to meaningfully interpret data on water quality and hydrological dynamics without knowledge of temporal and spatial variability of the hydrological regime. When the service is to maintain water quality or quantity by preserving the ecosystem in its current state, it might be possible to set up the system based on precautionary principle and leave detailed research for later (Asquith and Wunder 2008). However, when the service results from restoration, research will be needed to demonstrate the link between restoration activities and water quantity or quality.

Still, the project could help improve understanding of the water threshold requirements for certification. For example, measuring variables linked to water quality and quantity could generate better understanding of how these variables vary spatially and temporally, and thus whether a threshold value could be established that needs to be maintained for the water service to be and remain certified. Modeling software such as Integrated Valuation of Ecosystem Services and Tradeoffs (InVEST) (Nelson et al. 2009) could then be used to determine: (1) the current status of ecosystem services targeted by the program; (2) the potential for these ecosystem services to be restored and maintained via the program; and (3) the land management practices that could achieve ecosystem service delivery most efficiently.
Chapman (1996) identifies several variables that directly describe the quantity and quality of water: $\mathrm{pH}$, temperature, conductivity (i.e. total amount of dissolved ions), dissolved oxygen, biochemical oxygen demand, turbidity (i.e. how clear the water is), total dissolved and suspended solids, nutrient concentration, chemical composition, water level and discharge (i.e. stream flow). Also, it is possible to use water fauna, such as macroinvertebrates, as surrogates to track changes in water quality (biomonitoring). In addition to variables directly related to quantity and quality of water, precipitation, land-use changes and changes in forest resources in the watershed should be monitored (Johnson et al. 2001). Remote sensing methods could be employed to assess deforestation and large-scale forest degradation.

In addition to scientific indicators, it is possible to develop functioning local indicators for water quality monitoring (Table 2). For example, in Laos, Basuki (2011) first asked local villagers to identify drinking-water sources on a map and subsequently held discussions with the villagers about indicators. During group discussions, villagers identified indicators such as water color and the presence of certain animals. Based on those indicators, a local water-quality index was created; it was subsequently compared to the scientific water-quality index (based on a water monitoring kit that measures 13 physical and chemical variables), as well as to an index based on macroinvertebrates. The local 


\section{Box 7. Land use and hydrological services}

The relationship between land use and hydrology is complex, and established wisdom about their nature can also change over time. The following patterns are relatively well established (Bruijnzeel 2004; Asquith and Wunder 2008):

- Intact natural vegetation cover guarantees optimum stream flow under given geo-climatic conditions. It also affords maximum soil protection and therefore provides optimum regulation of seasonal flows while moderating erosion and stream sediment flows.

- Montane cloud forests and related cloud-affected ecosystems such as páramos provide maximum amounts of stream flow due to a combination of high rainfall, extra inputs from cloud water capture by the vegetation and low water-use due to frequent occurrence of fog.

- Intact natural vegetation cover per se is no guarantee that flood or landslides will not occur, especially in large-scale watersheds and under extreme weather events. However, their frequency will be less with intact vegetation than is usually observed after conversion.

- Removal of old-growth forest at large scales $\left(>10,000 \mathrm{~km}^{2}\right)$ in humid parts of the world reduces rainfall during the transition between rainy and dry seasons. Annual average effects are modest (5-10\%), but are higher during the transition.

- Removal of forest has an initial short-term effect of increasing annual water yield (published range $100-800 \mathrm{~mm}$ for a $100 \%$ change in land cover) with the size of the change depending on rainfall and degree of surface disturbance. Subsequent water yield depends on the new land cover.

- Converting forest to non-forest cover increases low flows (as long as soil degradation is kept moderate and mean annual precipitation totals in excess of potential evaporation, i.e. $\sim 1500 \mathrm{~mm}$ or more.)

- Converting forest to other uses is likely to lead to reduced low flows, if soil degradation has caused overland flow to exceed $\mathbf{1 5 - 2 0 \%}$ of rainfall. This degraded stage is typically reached after prolonged exposure of bare soil to the elements, by intensive grazing or the use of heavy machinery, too frequent or poorly timed use or occurrence of fire (hampering vegetation recovery), improper tillage regimes and by the introduction of compacted surfaces such as roads.

- Reforestation does not re-create the ecological conditions of old-growth forest within the lifespan of most PES programmes due to higher water use of the rapidly growing trees compared with that of the vegetation the trees are replacing.

- Reforestation is unlikely to reduce the risk of flooding to the same degree as the former old-growth forest because the recovery of degraded soils often takes decades. In addition, the impacts of development on drainage infrastructure (such as those associated with roads or housing) are not undone by tree planting.

- Establishing forest on grasslands or degraded savannas leads to reductions in low flows when the trees' increased water use is not offset by improved infiltration. For example, to compensate for the use of $300 \mathrm{~mm}$ of extra soil water by trees, a $30 \%$ switch from overland flow to infiltration is needed at an annual rainfall of $1000 \mathrm{~mm}$ /year to break even. This can only be expected where surface soils are partly degraded yet are deep enough to store the extra infiltrated water.

index was mostly consistent with the scientific index and performed better than the index based on macroinvertebrates.

Local communities can also be involved in a more scientific form of monitoring. For example, Le Tellier et al. (2009) showed that minimally trained local farmers could reliably collect rainfall and stream flow data. Although the data was not sufficiently high quality to fully explore the forest/water relationship, the authors are confident that such data collection is possible: for more efficient and effective data collection, only the most relevant hydrological criteria (as opposed to the scientifically complete criteria) should be monitored.

\subsubsection{Non-timber forest products}

Non-timber forest products (NTFPs) are considered to be any commodity obtained from the forest that does not necessitate harvesting trees. They are ecosystem goods rather than services. We discuss these here because certification of some ecosystem services might be bundled with certification of NTFPs.

NTFPs include game animals, fur-bearers, nuts and seeds, berries, mushrooms, oils, foliage, medicinal plants, peat, fuel wood and forage (Shanley et al. 2002). Considering the incredible diversity of species 


\section{Box 8. Rapid Hydrological Appraisal}

Jeanes et al. (2006) have developed a Rapid Hydrological Appraisal (RHA) method that helps stakeholders evaluate whether to purse formal negotiations between providers and beneficiaries of environmental services. An RHA takes about 6 months and consists of five steps:

1. Inception (month 1) Issues, stakeholders and site are scoped. Site-related documentation is collected and reviewed. Most work is office-based but field trip and initial stakeholder meeting take place.

2. Baseline data collection in the office (months 2-4)

Collection of site-related documentation continues and is broadened to include available data and maps of the watershed. The design of field surveys and overall work plan takes place.

3. Fieldwork (months 3-4)

Baseline data collection and ground truthing for spatial analysis take place. Participatory landscape analysis and surveys on local ecological knowledge and environmental knowledge of public and policy makers are conducted.

4. Data processing and scenario analysis (months 3-5)

Data from the previous phases are analysed and provide a base for modeling of possible future scenarios (e.g. by using GenRiver model).

5. Communication and refinement of findings (month 6)

At this stage the various perspectives on what is happening in the landscape are presented and clarified for all stakeholders. Final assessment of the opportunities for negotiation is discussed.

\section{Box 9. Economic valuation of watershed services}

Economic valuation of watershed can be classified into two categories: revealed preference methods and stated preference methods (Goldberg 2007). To place a monetary value on an environmental asset, revealed preference methods draw upon information pertaining to individual preferences for environmental and natural resources through direct or surrogate market comparisons. In terms of watershed valuation, this is most commonly done through either: (1) the hedonic pricing method (which estimates a statistical relationship between the attributes of specific surface-freshwater systems and the price of a good for which a market already exists in that same system) or (2) the production function method (which monetizes values of watershed goods and services by establishing a relationship between an environmental input and a resulting output, and then using current market prices of the output to value the environmental input). The stated preference method establishes a water price based on the willingness of buyers to pay for the associated services (Goldberg 2007). Further valuation approaches are discussed in the IUCN practical valuation guide (Emerton and Bos 2004).

in the world's forests, the range of NTFPs is very large. Perhaps the biggest problem in describing these products is the lack of information concerning distribution systems that get them to final consumers. NTFPs are found in a wide variety of outlets, unlike timber-based forest products (Chamberlain et al. 1998).

Since 1998, FSC has permitted certification of NTFP management systems on a case-by-case basis. The first FSC-approved NTFP certification, granted by SmartWood to a chicle (a tropical evergreen tree exudate used for chewing gum) operation in
Mexico, occurred in 1999. Since then, others have followed including: Açaí (Euterpe oleracea), maple syrup (Acer saccharum and closely related species), rubber (Hevea brasiliensis), Brazil nuts (Bertholletia excelsa), medicinal plants and venison (certified by SGS). Such products are mentioned in FSC's Product Classification (FSC-STD-40-004a V2-0 EN). Many other NTFPs are being developed for certification, including bamboo, rattan, yerba mate (Ilex paraguariensis, made into a drink), and pine nuts (Pinus spp.) (Smartwood 2002), as well as chestnut (Castanea spp.) production in Greece and cork (Quercus suber) in Spain (Donovan 2000). 
Table 2. Possible indicators to monitor the provision of water services.

\begin{tabular}{|c|c|}
\hline Possible indicators & Advantages and disadvantages \\
\hline \multicolumn{2}{|c|}{ Changes in natural vegetation of the forest area } \\
\hline Area of prevented deforestation & $\begin{array}{l}+ \text { Easy to monitor by remote sensing or by systematic forest inventories. } \\
\text { - Both types of monitoring can be costly; tells nothing about the condition } \\
\text { of the forest. }\end{array}$ \\
\hline Sustainable harvest levels & $\begin{array}{l}+ \text { Rather easy to monitor once the level for sustainable harvesting is known. } \\
\text { - Difficult to estimate sustainability threshold; harvesting levels may not be } \\
\text { honestly reported. }\end{array}$ \\
\hline Sustainable harvesting practices & $\begin{array}{l}\text { Information about the harvesting practices easy to get from management } \\
\text { plans and/or by interviewing people; has a direct relationship to forest } \\
\text { condition. } \\
\text { - Ground truthing needed to verify information, which can be costly. }\end{array}$ \\
\hline $\begin{array}{l}\text { Buffer zones along water courses and } \\
\text { water bodies }\end{array}$ & $\begin{array}{l}\text { + Easy to monitor compliance. } \\
\text { - An effective buffer width may be difficult to establish. }\end{array}$ \\
\hline \multicolumn{2}{|l|}{ Water quality } \\
\hline Nutrient concentration & $\begin{array}{l}\text { + Methods for taking water samples well established. } \\
\text { - }\end{array}$ \\
\hline Chemical composition & $\begin{array}{l}\text { - Methods for taking water samples well established; gives a } \\
\text { comprehensive data of pollutants. } \\
\text { - Difficult to determine all of the biological effects that results from a } \\
\text { particular composition of chemicals; can be expensive; point measure tells } \\
\text { nothing about accumulation effects. }\end{array}$ \\
\hline Macroinvertebrates & $\begin{array}{l}\text { + Sampling relatively easy and cheap; usually macroinvertebrates are } \\
\text { relatively sedentary so occurrence can be related to the place of capture; } \\
\text { respond to environmental stress and hence can show effects of short term } \\
\text { perturbations. } \\
\text { - Expertise may be needed to identify some of the groups thus, increasing } \\
\text { costs; ecological knowledge needed to avoid mistakenly relating absences } \\
\text { (e.g. due to life cycle factors); sensitivity to chemical compounds can vary } \\
\text { between species. }\end{array}$ \\
\hline Odor & $\begin{array}{l}\text { - Easy to measure. } \\
\text { - Subjective; does not provide information about the nature of the problem } \\
\text { beyond the odor; the condition of the water may be relatively bad before } \\
\text { the problem is detected. }\end{array}$ \\
\hline Turbidity (i.e. clarity) & $\begin{array}{l}\text { Easy to measure; can provide an estimate of the total suspended solids } \\
\text { (TSS) concentration, which is otherwise difficult to measure. } \\
\text { - Does not provide specific information about the chemical or } \\
\text { microbiological composition of the water. }\end{array}$ \\
\hline Conductivity & $\begin{array}{l}+ \text { Low cost method; depending of the equipment results may be obtained } \\
\text { immediately. } \\
\text { - Does not provide specific information about the composition of the ions or } \\
\text { microbial contaminants. }\end{array}$ \\
\hline $\mathrm{pH}$ & $\begin{array}{l}\text { + The concept of } \mathrm{pH} \text { is relatively well known and easy to understand. } \\
\text { - Change in } \mathrm{pH} \text { does not indicate the specific chemical composition. }\end{array}$ \\
\hline Temperature & $\begin{array}{l}\text { + Easy and quick to measure. } \\
\text { - Does not provide information about chemical or microbiological state. }\end{array}$ \\
\hline
\end{tabular}


Table 2. Continued

\begin{tabular}{|c|c|}
\hline Possible indicators & Advantages and disadvantages \\
\hline Biochemical oxygen demand (BOD) & $\begin{array}{l}\text { Easy and low cost to measure; can reproduce oxygen consumption similar } \\
\text { to that occurring in real water bodies as a natural process. } \\
\text { - Does not represent the total amount of organic matter, but only the } \\
\text { biodegradable part of it; not a suitable pollution indicator for eutrophic } \\
\text { water bodies because oxygen consumption by autotrophic organisms } \\
\text { (e.g. algae) contained in water samples from these water bodies causes } \\
\text { significant errors in BOD values. }\end{array}$ \\
\hline Dissolved oxygen (DO) & $\begin{array}{l}+ \text { Good indicator of the health of the water body as all oxygen is essential } \\
\text { for all aquatic life; easy to measure; test results immediate; relatively } \\
\text { cheap. } \\
\text { - DO levels fluctuate seasonally and within 24-hour period. }\end{array}$ \\
\hline Total dissolved and suspended solids & $\begin{array}{l}+ \text { An aggregate indicator for chemicals; depending on the method results } \\
\text { can be obtained immediately; methods to measure are well known. } \\
\text { - Fluctuate seasonally; the test does not identify the specific ion responsible } \\
\text { for change; can be difficult to measure. }\end{array}$ \\
\hline Recreational and cultural value & $\begin{array}{l}+ \text { The use of the water body easy to determine } \\
\text { - The value of the use may be difficult to determine; data collection may be } \\
\text { time consuming. }\end{array}$ \\
\hline \multicolumn{2}{|l|}{ Water quantity } \\
\hline Water level & $\begin{array}{l}\text { + Relatively easy to measure. } \\
\text { - Bottom morphology may change, e.g. in rivers, thus adding variability. }\end{array}$ \\
\hline Streamflow & $\begin{array}{l}\text { + Relatively easy to measure and monitoring can be done at relatively low } \\
\text { cost. } \\
\text { - Difficult to interpret without knowledge of temporal variability of the } \\
\text { hydrological regime; establishing whether there is a relationship between } \\
\text { streamflow and management actions will require long time. }\end{array}$ \\
\hline Baseflow volume & $\begin{array}{l}\text { + Relatively easy to measure and monitoring can be done at relatively low } \\
\text { cost. } \\
\text { - Difficult to interpret without knowledge of temporal variability of the } \\
\text { hydrological regime; establishing whether there is a relationship between } \\
\text { baseflow and management actions will require long time. }\end{array}$ \\
\hline Precipitation & $\begin{array}{l}\text { + Easy to measure; well-established methods. } \\
\text { - Does not tell about the success of the forest management as such; rather } \\
\text { acts as a complementary indicator for stream flow measurement. }\end{array}$ \\
\hline
\end{tabular}

As NTFPs tend to play an important role in rural people's livelihoods, it is sensible to involve rural people in the management of the resource. Stockdale (2005) identified seven steps to sustainable community-based NTFP management (Box 10). The most effective way to develop a communitybased management plan is to involve all community members. It is also worth considering other groups (e.g. NTFP users outside the community that may have a stake in NTFP management) and involve them as appropriate. To help decide what weight to put on different groups' opinions in regard to the management of NTFPs, stakeholders can be divided to primary stakeholders (who depend on forest resource for survival) and secondary stakeholders (who have less vital interest in the resource) (Stockdale 2005).

In terms of certification of NTFPs, there are two options: either demonstrate the goods were harvested from a forest that has been FSC certified or certify the NTFPs. Nevertheless, project management will likely need to demonstrate that the NTFPs are managed sustainably. Therefore, indicators linked to the level of production, such as total amount of product collected versus natural production of the 
Box 10. Steps to sustainable and community-based NTFP management after Stockdale (2005)

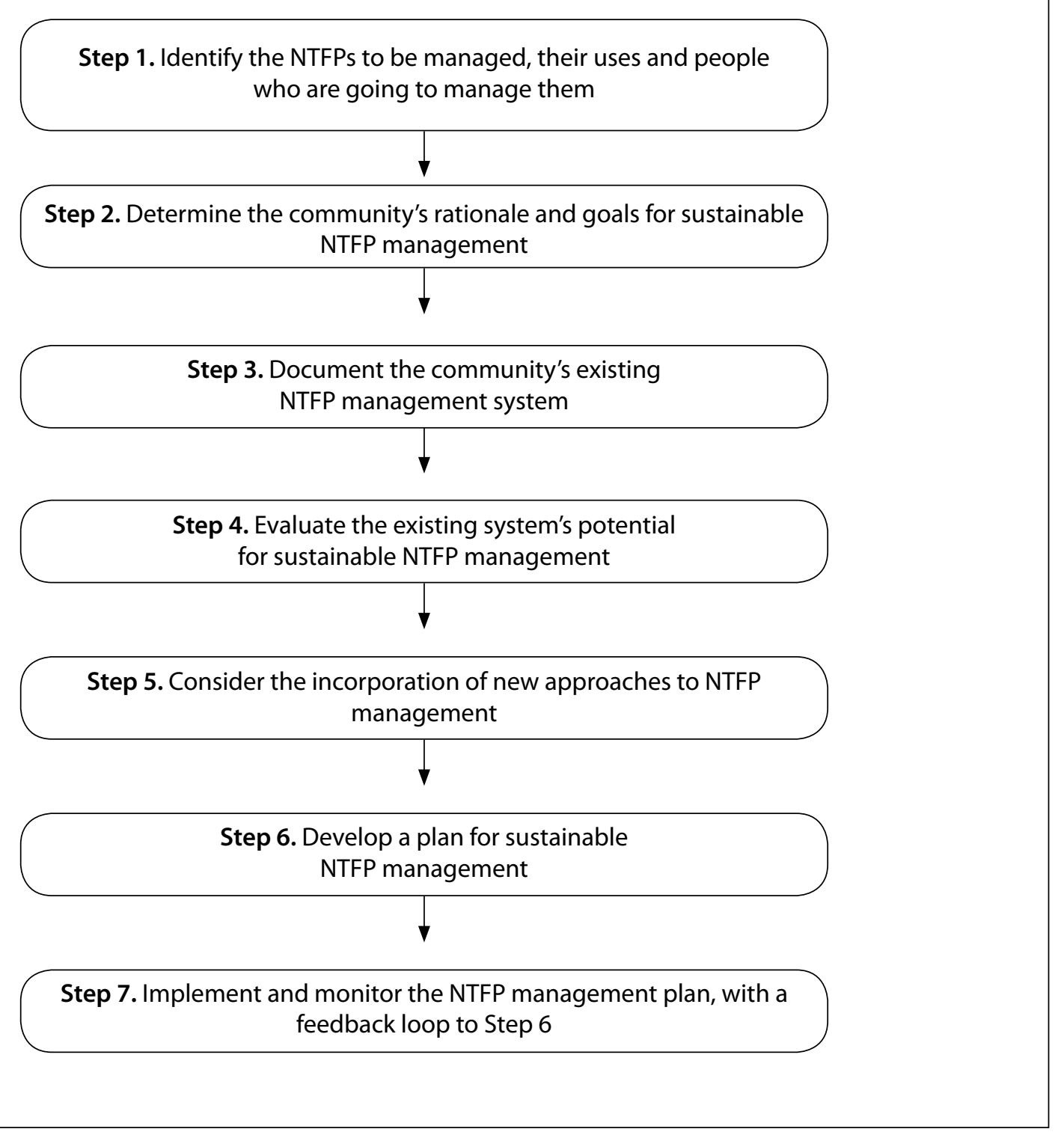

good, will be needed to demonstrate that harvesting levels are sustainable (Table 3). Other factors that affect the sustainability of harvest: the method of how the product is harvested, the condition of the harvested product, how often it is harvested, and when it is harvested (Lawrence et al. 2008).

Harvest records are an easy way for communities to keep track of NTFPs harvested. The data can be recorded either at the time and place of the harvest or later at NTFP collection points, markets or households (Stockdale 2005). In addition to yield, quality of harvested NTFPs and the timing of harvest can also be recorded. When a more detailed picture of the NTFP harvest is desired, the community can undertake, possibly with some outside help and guidance, a resource inventory; the recovery and regeneration times can also be researched. A resource inventory data and/or data on recovery time can help assess the sustainable harvesting level. Similarly, looking at regeneration times can paint a better picture of sustainable yield. Besides the yield, indicators linked to harvesting impact should be used, for example, to calculate how often the product is harvested annually, whether appropriate harvesting practices are used and the extent to which harvesting of NTFPs damages the forest ecosystem (Ritchie et al. 2000). 
Box 11. NTFPs and timber's relative characteristics with regard to certification (Shanley et al. 2008)

\begin{tabular}{|c|c|c|}
\hline Key issues & Timber & Non-timber forest products \\
\hline $\begin{array}{l}\text { Technical issues } \\
\text { involved in } \\
\text { assessments }\end{array}$ & $\begin{array}{l}\text { - less complex chain of custody } \\
\text { - } \text { relatively well-established } \\
\text { guidelines and clear procedures } \\
\text { - ecological standards widely } \\
\text { accepted (FSC, PEFC, SFI) timber and } \\
\text { derivatives not ingested, therefore } \\
\text { no hygiene and quality control } \\
\text { issues }\end{array}$ & $\begin{array}{l}\text { - complicated, lengthy chain of custody } \\
\text { - incipient, ad hoc guidelines } \\
\text { - uncertain procedures } \\
\text { - multiple standards apply (i.e., organic, fair } \\
\text { trade, ecological) } \\
\text { - site-specific standards difficult to apply to } \\
\text { some NTFPs } \\
\text { - quality control issues are paramount for } \\
\text { edible and medicinal plants, adding an extra } \\
\text { layer of complexity }\end{array}$ \\
\hline Ecological & $\begin{array}{l}\text { - considerable data for developing } \\
\text { management plans (fewer for lesser } \\
\text { known tropical species) } \\
\text { - predictable production/yield } \\
\text { - moderately variable quality }\end{array}$ & $\begin{array}{l}\text { - lack of ecological data to design } \\
\text { management plans (except for a few highly } \\
\text { valued species) } \\
\text { - highly irregular and unpredictable } \\
\text { production } \\
\text { - highly variable quality }\end{array}$ \\
\hline $\begin{array}{l}\text { Economic/ } \\
\text { markets }\end{array}$ & $\begin{array}{l}\text { - moderate to high economic return } \\
\text { (except for lesser known tropical } \\
\text { species) } \\
\text { - stable to growing national and } \\
\text { international markets } \\
\text { - gradually emerging demand for } \\
\text { certified wood, especially in Europe } \\
\text { and N. America } \\
\text { - certification affordable to larger } \\
\text { industries (more challenging } \\
\text { for smaller operations and } \\
\text { communities) } \\
\text { - incipient consumer demand }\end{array}$ & $\begin{array}{l}\text { - low economic return } \\
\text { - local markets and direct use predominate } \\
\text { - unpredictable, niche markets; international } \\
\text { NTFP markets subject to 'boom-bust' and } \\
\text { substitution } \\
\text { - certification generally unaffordable without } \\
\text { subsidies, unless carried out as part of a forest } \\
\text { management certification that includes } \\
\text { timber } \\
\text { - low consumer demand, confusion over } \\
\text { labeling of NTFPs }\end{array}$ \\
\hline Social & $\begin{array}{l}\text { - social issues range from simple to } \\
\text { complex (depends on context) } \\
\text { - some cases of local incentives in } \\
\text { temperate forests triggered by } \\
\text { consumer demand } \\
\text { - industries possess organizational } \\
\text { capacity, capital and information } \\
\text { (not so for community forestry and } \\
\text { small operations) } \\
\text { tenure less of an issue for timber } \\
\text { extraction than non-timber harvest }\end{array}$ & $\begin{array}{l}\text { - social issues usually exceedingly complex } \\
\text { (especially in developing countries) } \\
\text { - little to no local incentives for NTFP } \\
\text { certification } \\
\text { - low-intensity producers lack organizational } \\
\text { capacity, capital, information and power } \\
\text { - many gatherers have insecure tenure or } \\
\text { access to NTFP resources } \\
\text { - poor wages/prices for goods and difficult } \\
\text { working conditions }\end{array}$ \\
\hline
\end{tabular}

\subsubsection{Biodiversity}

FSC certification pays significant attention to the identification of rare and threatened species and ecosystems and requires their regular monitoring to ensure compliance with the standard. A vast literature exists on species and ecosystem monitoring, while more specific resources also abound with regard to the identification and monitoring of High Conservation Value Forests (HCVF). However, many of these approaches require the identification and monitoring of all IUCN redlisted and protected species, which is practically unachievable (Meijaard and Sheil 2012) There 


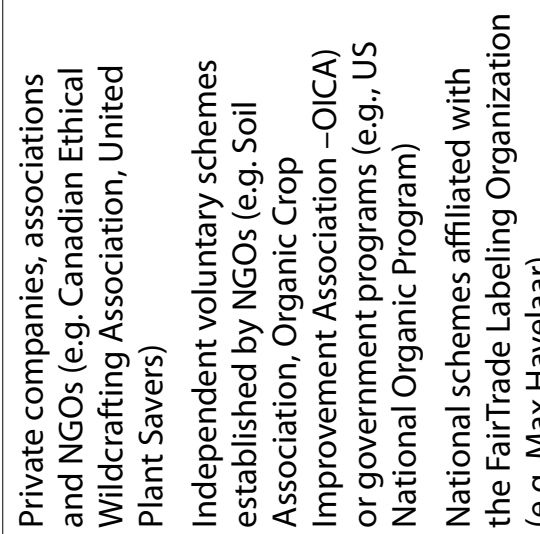

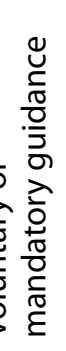

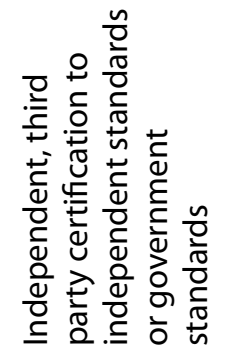

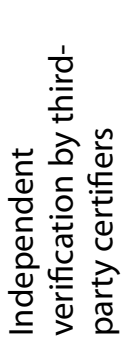<smiles>[CH]=[CH]</smiles>

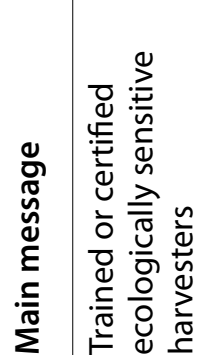

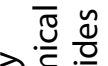

要

$\stackrel{4}{\underline{y}}$

है

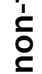

$\stackrel{\circ}{\circ}$

हैำ

흔

政

氖

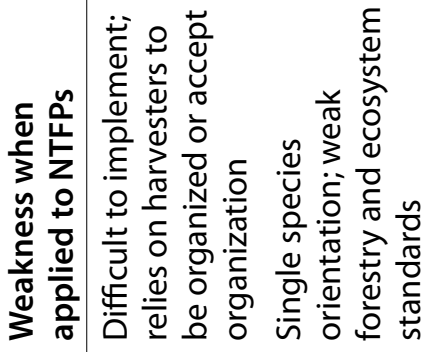

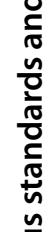

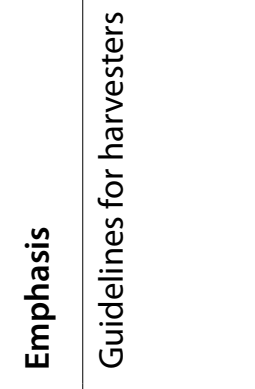

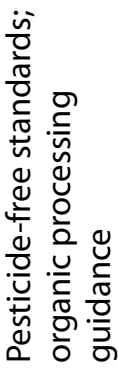

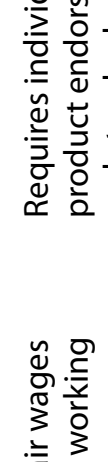

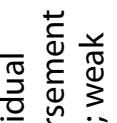

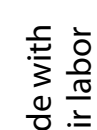

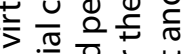

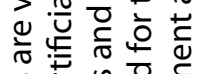

苋

บั

o 它

$\stackrel{\frac{0}{5}}{\frac{0}{5}}$

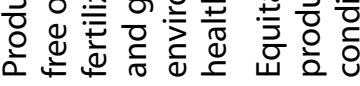

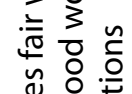

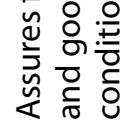

แั

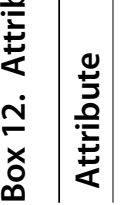

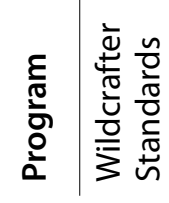

Oั

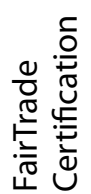

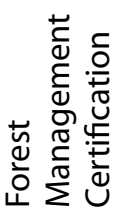



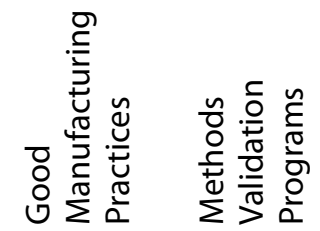

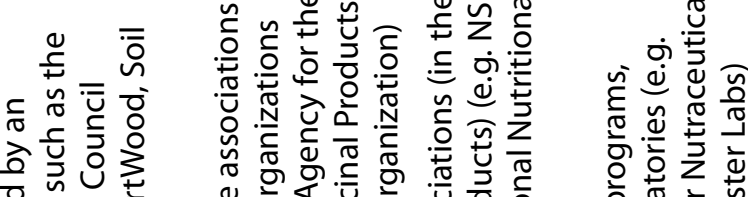

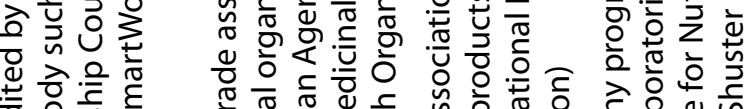

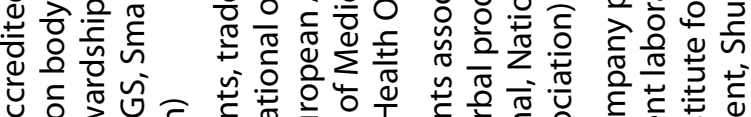

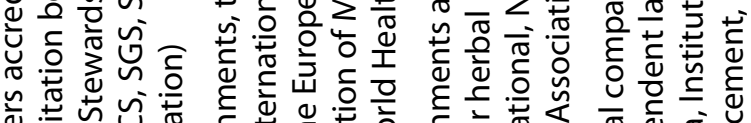

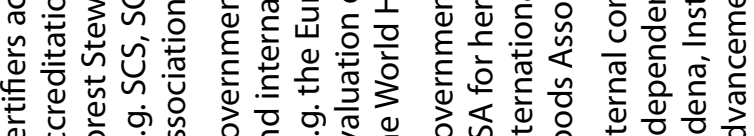

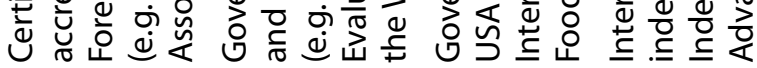

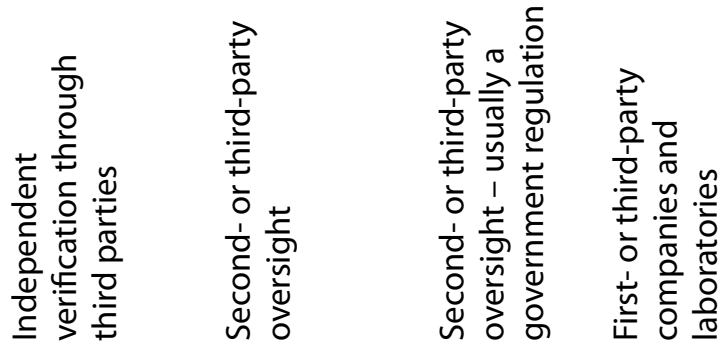

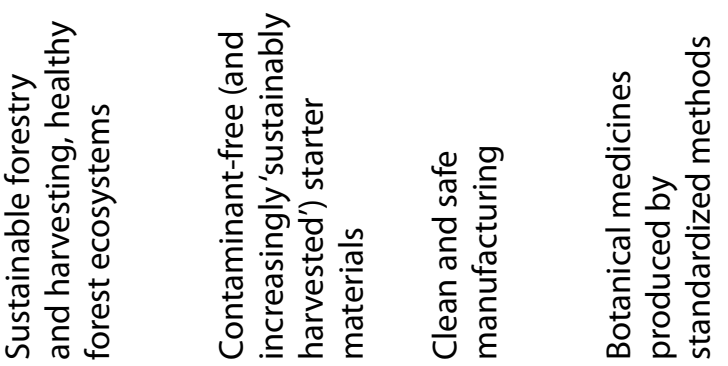

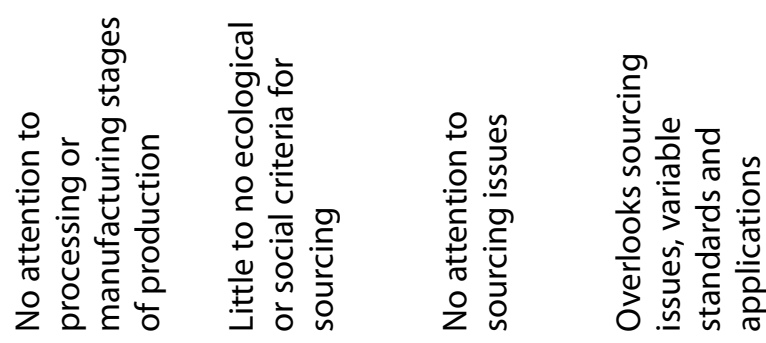

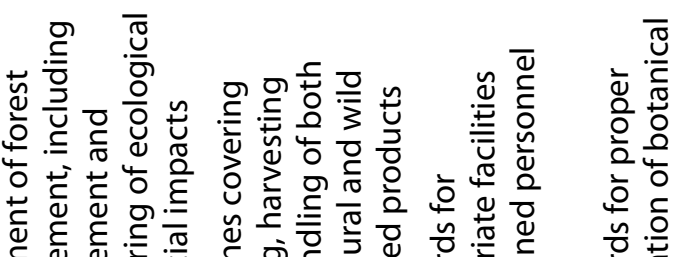

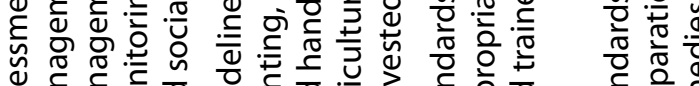

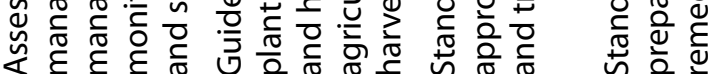

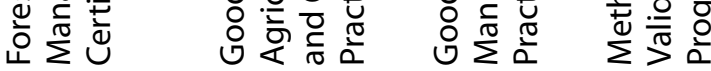


Table 3. Possible indicators to monitor forest condition and NTFP management.

\begin{tabular}{|c|c|}
\hline Possible indicators & Advantages and disadvantages \\
\hline \multicolumn{2}{|l|}{ Changes in natural vegetation of the forest area } \\
\hline Area of prevented deforestation & $\begin{array}{l}+ \text { Easy to monitor by remote sensing or by systematic forest } \\
\text { inventories. } \\
\text { - Both types of monitoring can be costly; tells nothing about the } \\
\text { condition of the forest. }\end{array}$ \\
\hline Sustainable harvest levels to prevent degradation & $\begin{array}{l}\text { + Easy to monitor from harvesting records. } \\
\text { - It might be difficult to estimate sustainability threshold, e.g. if } \\
\text { the yield varies greatly; harvesting levels may not be honestly } \\
\text { reported. }\end{array}$ \\
\hline \multicolumn{2}{|l|}{ Sustainable harvesting } \\
\hline Sustainable harvesting practices & $\begin{array}{l}\text { + Information about the harvesting practices easy to get from } \\
\text { management plans and/or by interviewing people; has a } \\
\text { direct relationship to forest condition. } \\
\text { - Ground truthing needed to verify information, which can be } \\
\text { costly. }\end{array}$ \\
\hline $\begin{array}{l}\text { The condition of harvested product (i.e. product } \\
\text { quality) }\end{array}$ & $\begin{array}{l}+ \text { Easy to monitor from harvesting or sales records. } \\
\text { - Does not tell about the condition of forest or management } \\
\text { practices. }\end{array}$ \\
\hline Timing of harvest & $\begin{array}{l}\text { + Easy to monitor from management plans and/or by } \\
\text { interviewing people; related to the yield. } \\
\text { - Harvest times may vary between years, and hence, optimal } \\
\text { timing may require repeated observations. }\end{array}$ \\
\hline \multicolumn{2}{|l|}{ Regeneration and recovery time } \\
\hline & $\begin{array}{l}\text { + Relates directly to the forest condition and sustainability of } \\
\text { harvest; the current harvesting cycle easy to monitor from } \\
\text { management plans and/or by interviewing people. } \\
\text { - Establishing regeneration and recovery times (i.e. the optimal } \\
\text { length of a harvesting cycle) can take long time depending on } \\
\text { the product; requires repeated observations and thus can be } \\
\text { costly. }\end{array}$ \\
\hline Preventing illegal harvesting & $\begin{array}{l}+ \text { Easy to see whether action have been taken to prevent illegal } \\
\text { harvesting. } \\
\text { - Can be expensive. }\end{array}$ \\
\hline
\end{tabular}

are too many species of potential conservation concern, while many find taxonomic identification to be problematic (Box 12). Any species-based monitoring system, therefore, needs to carefully consider what is pragmatic versus a scientific ideal. Currently, the various HCVF toolkits give methodological guidance as to how biodiversity could be monitored under an FSC framework. Given sufficient resources and expertise, these toolkits might facilitate monitoring. However, the approaches need to be adapted so that smaller businesses and smallholders can also afford to implement them without permanent inputs from expensive specialists.
When designing monitoring programmes in PES schemes for biodiversity conservation, Sommerville et al. (2011) point out that decisions must be made concerning indicators, how they will be monitored and how the monitoring information will be used to differentiate payments (e.g. trends over time, performance relative to neighbouring sites, performance against a target) (Figure 6). Before selecting indicators, it is important to clearly define the ecological or conservation issue, i.e. the purpose of the use of the indicator (Heink and Kowarik 2010). Then the following can be determined (1) which aspect of biodiversity should be indicated; (2) whether changes should be measured over 
time or if inventories are needed; (3) whether indicators are to describe or evaluate biodiversity or to set conservation goals; or (4) whether effects on biodiversity and their causes should be identified.

Many studies employed participatory approaches for assessment, monitoring and evaluation of biodiversity (PAMEB). In addition to the general benefits of participatory approaches mentioned earlier, benefits of PAMEB also include the following: it can be faster than traditional scientific monitoring; results may be easier to translate into local management decisions than scientific information; assessments can provide ways to link to scientific information that is relevant to local needs and the wealth of traditional knowledge can be employed (Widman et al. 2003; Nanyunja 2006). There are, of course, limitations as well: forest users may have limited time available for monitoring; scientific rigidity is not guaranteed; illiteracy may hamper data collection and processing; equity issues affecting access to biodiversity and ownership of information may arise; and conflicts among different stakeholders may become apparent due to different interests in biodiversity (Widman et al. 2003).

Danielsen et al. (2005) proposed five generic methods suitable for locally based biodiversity monitoring in developing countries:

1. Patrol records either by rangers or other people involved in managing the resource. The method consists of filling out sheets with observations and records provided by local people on key species, habitats or the extent of resource use during patrols.

2. Transects. They can be employed either to collect data on changes in wildlife abundance or human resource use.

3. Species lists. This involves an assessment of the presence/absence of species on lists summarizing all the species encountered during a defined period of time.

4. Photography. This method, which consists of simple fixed-point photography from a suitable vantage point on the ground, shows if the size of important habitats is declining and why. Sometimes it might be possible to use photography to gather changes on animal abundance, mainly large mammals, but in general the method is not recommended for such use. Also, the method can be too expensive for some communities.
5. Village group discussions. This method is not a data collection method as such. However, it can be used in connection with the other methods or a small group of experienced forest product gatherers, hunters or fishers can do the monitoring and then share results in the discussions. This brings information to the attention of many people who can then suggest and/or endorse management options.

Of course, there are other methods as well. For example, to examine costs, accuracy and local reproducibility, Holck (2008) tested three different methods (20-trees method, Bitterlich gauge method, and disturbance checklist transect) with local participants to monitor forest disturbance and habitat loss. All the methods could describe the difference in disturbance, but the Bitterlich gauge method and disturbance checklist transect showed more consistent results than the 20-trees method. All the methods were low cost and after one day of training local community members were capable of collecting accurate data. The choice of method will depend on the objectives of the monitoring, the community implementing the monitoring and local conditions.

\subsubsection{Ecotourism}

There is a rapidly increasing number of ecotourism certification programmes, all with different selfmonitoring or third-party monitoring requirements. There do not appear to be any globally recognized standards with clearly defined criteria and indicators. Rainforest Alliance and Greenloons have produced a reference guide to compare the many different ecotourism certification standards. The Rainforest Alliance does not certify tour operators or hoteliers. Instead, they only verify that tour operators and hoteliers are implementing various social, economic and environmental criteria that are based on the Global Sustainable Tourism Criteria.

Ecotourism is often seen as a way to conserve biodiversity and, at the same time, improve livelihoods of local people. The thinking is that if a viable venture is linked to biodiversity of a site and generates benefits for the stakeholders who have sufficient capacity, then stakeholders will act to counter the threats to the resource (Salafsky and Wollenberg 2000). In reality, community-based 


\section{Box 13. Biodiversity monitoring under FSC}

Forest management guidance under FSC requires the detection, identification and management of endangered and nationally protected species. This is not easy. Let's consider the example of plants on the island of Borneo. Based on a density of some 6000 trees ha- $(\mathrm{dbh}>=1 \mathrm{~cm})$, an average 50000 ha concession in tropical forest contains around 300 million trees of 3000-4000 species (Losos and Leigh 2004). Based on daily identification rates of 55 samples (Slik personal communication), identifying each tree would take 500 taxonomists over 30 years (more if we consider regrowth over the same period). The situation for fauna would be comparable but may be even harder to claim as 'complete', because many mobile species can remain undetected or imperfectly identified.

Even focusing on species formally listed as having conservation significance poses considerable challenge. One could, for example, ignore all ants (Formicidae) because there are no IUCN red-listed or protected ant species on Borneo, but one would still need to consider a long list of plants and animals including tiny land snails (e.g. various critically endangered species of Arinia) or freshwater molluscs such as the endangered Brotia pageli, and such a list would take impossibly long to complete. A forest project in Indonesian Borneo could find itself looking for 701 IUCN-listed plant or animal species of near threatened to critically endangered status (IUCN 2010), of which some 150 are nationally protected (Noerdjito and Maryanto 2007). It is clear that, if rigorously sought, species-level identification for protected and endangered taxa could halt operations for decades and be tremendously costly.

In reality, of course, forest projects sidestep the challenge of identifying all red-listed and protected species. Even in tropical forest areas where taxa are relatively understudied and undersampled, projects employ short surveys involving a few available experts. The assumption is that a sample- based (or 'expert search') approach is sufficient to reveal which species of concern occur. This compromise will inevitably allow some species and their vulnerabilities to go undetected and thus unconsidered. It seems that a partial and thus imperfect survey matters more for some species than others, although a clear consensus is unlikely. If one endangered orangutan (Pongo pygmaeus) was killed during project management this would likely cause an outcry. Who then decides which species require what treatment? Guidelines such as Indonesia's High Conservation Value Tool Kit (HCV Consortium 2009), which is commonly used to identify areas of biodiversity importance, require populationlevel management for threatened and endangered plants, but management at the individual level for animals. This level of generalization is unrealistic: who could manage animal species such as the vulnerable dragonfly Coeliccia flavostriata or the Bornean water shrew Chimarrogale phaeura? Currently guidelines are insufficient and any decision would be open to dispute.

The problem is compounded by ongoing discoveries of new species, many of which will be based on a few specimens from one or two areas. Following the taxonomic description of these taxa, they will likely be considered to be threatened because of their small known-range. This could rapidly increase the list of species a tropical forest project would have to monitor to fulfil FSC criteria.

The above suggests that new approaches are needed for measuring and monitoring biodiversity in an FSCcertification context. It might be more practical and pragmatic to limit biodiversity surveys and monitoring to a pre-defined group of species with either high conservation importance (e.g. tigers, orangutans), high importance to local communities (e.g. pigs, certain fish), or important ecological roles (e.g. hornbills). Such lists could be compiled at a country or sub-country level, reviewed by experts and then approved by the FSC. Based on such lists, country-wide maps could be generated that would indicate that certain species occur in certain forest areas, thus narrowing down the list of species a particular project should monitor. The lists would have to be accompanied by survey methods and identification tools so that these areas are standardized at least at the country level. Such data sets could then provide the basis for all forest biodiversity monitoring in an FSC certification context.

ecotourism can lead to biodiversity conservation, but that will depend on a number of factors such as the degree of community involvement in the ownership and management of the venture, the level of management and bookkeeping skills, the extent to which community members use skills and technologies they already possess and market conditions (Salafsky et al. 2001). Also, initial 
technical and financial assistance from external donors may be needed to support the venture (Frost and Bond 2008). However, due to its localized scale, the impact of ecotourism on biodiversity conservation is likely to be limited (Kiss 2004).

To monitor the impact of the ecotourism venture on biodiversity conservation, it is necessary to establish conservation goals and have baseline data, e.g. existing resource or land-use patterns or population density (if the goal is to conserve certain species). As the goal of an ecotourism venture is to improve livelihoods, then livelihood benefits should be monitored. However, monitoring should not be limited to financial benefits as noncash benefits can greatly influence the stakeholders' willingness to act against threats (Salafsky et al. 2001). Also, since the distribution of economic benefits has often been uneven and only a small portion of the community has benefitted, the distribution of benefits should be monitored (Salafsky et al. 2001; Kiss 2004). If payments are non-differentiated (i.e. not related to contribution of revenues), they may weaken the incentive for conservation (Frost

\section{Possible indicators}

\begin{tabular}{|l|}
\multicolumn{1}{c|}{ Individual species } \\
+ Is biodiversity of interest, or \\
has a direct relationship to \\
the service. \\
- If rare or variable, may be \\
challenging to monitor.
\end{tabular}

\begin{tabular}{|l|}
\multicolumn{1}{|c|}{ Threats } \\
+ Has a direct relationship to \\
the service, may respond \\
to management more \\
quickly than service. \\
- If rare or variable, may be \\
challenging to monitor. \\
Dating the threat's age \\
(pre or post intervention) \\
may be difficult.
\end{tabular}

\begin{tabular}{|l|}
\multicolumn{1}{|c|}{ Habitat } \\
+ Change can be monitored \\
over large areas \\
consistently with remote \\
sensing. \\
- Relies on assumption that \\
if habitat is present, service \\
is present; challenging to \\
pick up degradation.
\end{tabular}

\begin{tabular}{|l|}
\hline \multicolumn{1}{|c|}{ Positive actions } \\
+ Easily monitored, as service \\
providers have incentive to \\
document evidence. \\
- Relationship between \\
positive actions and service \\
provision may be weak, for \\
example with governance \\
indicators.
\end{tabular}

\begin{tabular}{|l|}
\hline \multicolumn{1}{|c|}{ Ground based } \\
+ Can monitor service \\
directly. \\
- Costly to access many \\
sites and large number of \\
samples needed for \\
suitable power.
\end{tabular}

\begin{tabular}{|l|}
\hline \multicolumn{1}{|c|}{ Remote sensing } \\
+ Able to monitor \\
consistently across large \\
areas. \\
- Costly to access and treat \\
some types of remote \\
sensing data. Limited \\
ability to detect \\
degradation or individual \\
species. \\
\hline
\end{tabular}

How to differentiate payments
Trend over time at a site

+ Indicators for conservation that provides knowledge of status change.

- Information on positive and negative change only may be misleading, as stable but abundant indicators may provide greater service than small but increasing indicators.

Difference between sites

+ May motivate competition between providers; and an intuitive way to split a fixed budget among a set of providers.

- Not necessarily informative of trends or status of population.

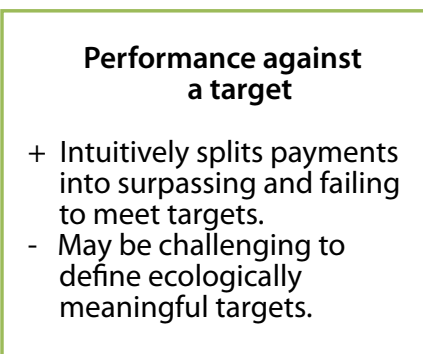

\section{Presence at a site}

+ Allows consideration of rare indicators.

- Differences may be due to true absence of indicators or reduced detectability.

Figure 6. An overview of possible approaches to monitoring biodiversity (Sommerville et al. 2011). 
and Bond 2008); hence, care should be taken when designing payment schemes. Other social indicators, such as representativeness and participation, are also relevant, especially where outsiders are involved. Power relations can be unequal between communities and other stakeholders, (e.g. NGOs, government agencies), and therefore, communities may not have a real say in management decisions (Coria and Calfucura 2012). For possible indicators, refer to the indicators of biodiversity and social impacts.

\subsection{Indicators for assessing the social impact of certification of ecosystem services}

Current FSC Principles and Criteria for Forest Stewardship provide a good starting point for the development of social impact indicators for certification of ecosystem services. The FSC standards are discussed later in this report and hence, we will not go into detail here. Instead, social impact indicators related to various PES schemes are discussed as a basis for certification schemes (Box 1; Table 4).

The indicators should reflect three principles of good governance: transparency, participation and accountability (Brito et al. 2009). Transparency refers to the sharing of information to allow scrutiny of actions; attributes include timeliness, comprehensiveness, availability, comprehensibility of information and whether efforts are made to ensure information reaches affected and vulnerable groups as appropriate. Participation in this context means that all stakeholders have a chance to voice their opinions and concerns in regard to the planned PES scheme and to participate in decision making. Elements of participation include the use of appropriate or sufficient mechanisms to invite participation, the inclusiveness and openness of such processes and the extent to which the gathered input is taken into account. Accountability means the basis for basic decisions is clear and justified; systematic monitoring of processes takes place to ensure that contractual obligations are met; and there are means to protect the rights of the stakeholders effectively or to reconsider decisions.

As PES schemes are based on physical assets, relatively clear land rights are important for effective implementation (Landell-Mills and Porras 2002; Asquith and Wunder 2008). This does not mean that sellers need to legally own the land. Instead, de facto rights to access, manage and use the land may be sufficient. The rights can be either individual or communal. Whether customary or statutory, the rights should effectively secure the tenure since markets can increase competition for control over forest land (Landell-Mills and Porras 2002). Once tenure rights are relatively clear, all landholders or land users in the area considered for the PES scheme should have equal right to participate, provided they meet the requirements of the scheme. Of course, it is possible that not everybody will want to participate and in some cases the requirements (e.g. the size of the farm or the amount of forest on the property) may prevent participation (Miranda et al. 2003). However, the requirements to participate should be clear and applied consistently to all potential participants. In addition to the above, the ability to undertake PES practices can differ among those willing to participate (Pagiola et al. 2005). Therefore, access to technical assistance should be provided.

For the sustainability of PES schemes, contracts need to be clear, effective and fair (Asquith and Wunder 2008). Also, all stakeholders need to perceive them as legitimate. Not only should formal rules and norms be respected in design and decision-making procedures of PES, but the scheme also needs to conform to informal rules and norms (Gross-Camp et al. 2012). One condition for PES is their voluntary nature. Therefore, participation in a PES scheme should be by choice rather than by regulation. The principle of free, prior and informed consent (FPIC) is important in this regard and the current FSC standards do require it. However, how FPIC is obtained is equally important. Bargaining power of different stakeholders can differ enormously and, therefore, it is important that contract partners have access to the negotiation support if needed (van Noordwijk et al. 2007). Also, all the information should be accessible to all stakeholders regardless of gender, wealth or level of literacy. In regard to communities, representation needs to be legitimate, i.e. engaging those who can speak for the community. Gender-based differences in perspective and preference should be taken into account and all perspectives effectively represented (van Noordwijk et al. 2007). This means not only involving women in negotiations, but ensuring their voice is heard. Representation is linked to influence. Communities should be engaged early enough to give them a chance to help shape the kind and type of intervention, as well as a chance to influence the rules of the game in all project stages (UNDESA 2005). 
The roles and responsibilities of the parties should be discussed and clearly stated in the contract to avoid misunderstandings - due to different cultural backgrounds, for example. The contracts should include provisions for renegotiation, termination and renewal. It is especially important to include a clause for renegotiation as unfairness of a deal often emerges after implementation has begun (Katoomba and UNEP 2008). Also, the situation may change through actions beyond the control of the sellers. Renegotiation clauses may, for example, adjust according to prices paid over time or allow for a re-evaluation of service value either periodically or due to new information. Finally, the contracts should include clauses that protect sellers against force majeure (e.g. extreme climatic event) (van Noordwijk et al. 2007).

It has been argued that PES schemes are sustainable only if they benefit the local communities (Landell-

Table 4. Possible indicators to monitor social impacts of the ecosystem services scheme.

\begin{tabular}{|c|c|}
\hline Possible indicators & Advantages and disadvantages \\
\hline Clear land rights & $\begin{array}{l}\text { + Key indicator. Statutory rights easy to verify. } \\
\text { - Customary rights might be difficult to verify. }\end{array}$ \\
\hline Legitimate contracts & $\begin{array}{l}+ \text { Easy to verify. } \\
\text { - Does not tell how the contracts were obtained. }\end{array}$ \\
\hline Free and Prior Informed Consent (FPIC) & $\begin{array}{l}+ \text { Key indicator. Easy to verify. } \\
\text { - Does not include information about how the FPIC was } \\
\text { obtained. }\end{array}$ \\
\hline $\begin{array}{l}\text { Equal right to participate in the ecosystem } \\
\text { services scheme }\end{array}$ & $\begin{array}{l}\text { + Easy to monitor whether criteria to ensure equity in } \\
\text { participation are in place. } \\
\text { - May be time consuming and rather difficult to verify that } \\
\text { criteria have been followed in practice. }\end{array}$ \\
\hline $\begin{array}{l}\text { The possibility to participate in decision-making } \\
\text { (e.g. were stakeholder consultations held) }\end{array}$ & $\begin{array}{l}\text { + Relatively easy to monitor; Links stakeholders to the decision- } \\
\text { making. } \\
\text { - Does not guarantee that views of the stakeholders were heard } \\
\text { or taken into account. }\end{array}$ \\
\hline $\begin{array}{l}\text { Representativeness of different groups in } \\
\text { stakeholder consultations }\end{array}$ & $\begin{array}{l}\text { + Relatively easy to monitor; links stakeholders to the decision- } \\
\text { making; possibility of monitoring gender equity. } \\
\text { - Does not guarantee that views of the stakeholders were taken } \\
\text { into account. }\end{array}$ \\
\hline Information availability and access to information & $\begin{array}{l}\text { + Links stakeholders to the decision making. } \\
\text { - May be difficult to monitor. }\end{array}$ \\
\hline $\begin{array}{l}\text { Negotiation support to the groups that have weak } \\
\text { bargaining power }\end{array}$ & $\begin{array}{l}\text { + Easy to monitor. } \\
\text { - The presence of negotiation support is not an indication of } \\
\text { quality. }\end{array}$ \\
\hline Access to technical assistance. & $\begin{array}{l}\text { Has a direct bearing on the ability of participants of the } \\
\text { PES scheme to undertake PES practices; provides valuable } \\
\text { information in regard to substandard management practices. } \\
\text { - Does not tell about the quality of the assistance. }\end{array}$ \\
\hline Financial and other forms of benefits & $\begin{array}{l}\text { Easy to monitor; directly relates to the sustainability of the } \\
\text { scheme. } \\
\text { - Monitoring may be time consuming. }\end{array}$ \\
\hline Existence of benefit sharing mechanism & $\begin{array}{l}\text { + Easy to monitor; directly relates to the sustainability of the } \\
\text { scheme. } \\
\text { - The existence of the mechanism is not a proof of use. }\end{array}$ \\
\hline Benefit distribution & $\begin{array}{l}\text { + Directly relates to the sustainability of the scheme. } \\
\text { - Monitoring may be time consuming. }\end{array}$ \\
\hline
\end{tabular}


Mills and Porras 2002). There are several ways to assess impacts of PES schemes (Schreckenberg et al. 2010). The Sustainable Livelihoods Framework (Carney 1998) analyses people's livelihood strategies built on different assets (financial, social, natural, physical and human), and is informative about the causal processes reducing or increasing well being. In the PES schemes, the most obvious benefit is the payment itself. However, the real financial benefit is revealed only after the opportunity costs of adopting the PES-promoted land-use practices are accounted for (Pagiola et al. 2005). In addition to financial payments, in-kind payments (such as technical training) and other motivations (such as existence values) can be incentives for providers to adopt the PES scheme (Kosoy et al. 2007; Fisher 2012). There are also other benefits for the communities.
Implementation of a PES scheme can contribute to building social capital through, for example, enhanced cooperation among the community, It can also improve general well being through, for example, better water quality.

From the social perspective, benefits are important but so is their distribution. Whether the benefits are distributed to the households or communities, the mechanism should be transparent, objective and fair. When the compensation is directed to communities there are additional requirements: the management of the funds should be transparent and decisions on use of the funds should be taken together in a representative manner and be perceived as fair by all the stakeholders. 


\section{Monitoring compliance with certification standards}

\subsection{Existing FSC standards as a basis for compliance monitoring indicators and their relevancy for certification of ecosystem services}

\section{In summary:}

- Current FSC standards provide a good basis for developing compliance monitoring indicators for forest management for provision of ecosystem services.

- However, additional indicators that are relatively cheap and simple to measure are needed.

One of the goals of the ForCES project is to develop scientifically derived verifiable compliance monitoring indicators for forest management for ecosystem services. These indicators should have global relevance, be relatively cheap and simple to measure and preferably fit existing FSC criteria. New indicators could borrow from existing ones in these standards because some standards in existing FSC forest management certification could feed right into the ecosystem service provision. For example, reduced impact logging (RIL) could play a role in carbon storage and even carbon sequestration if natural regeneration is managed, or not cutting riparian trees should protect water provision in logged landscapes. Presently, FSC provides little guidance on, for example, how RIL saves carbon. One possible approach within the ForCES context is, therefore, to establish the quantity and quality of ecosystem services that existing FSC standards might provide if properly applied. Below some existing FSC standards are discussed.

\subsubsection{FSC Forest Certification}

FSC Principles and Criteria for Forest Stewardship (FSC-STD-01-001 (version 5-0) EN) is based on 10 main principles that form a good foundation for building standards for certification of ecosystem services. In the following text, the principles and criteria (in italics) are discussed.

\section{Principle 1: Compliance with laws}

This principle and its criteria are applicable to certification of ecosystem service almost as is. Below we suggest some additions.

The Organisation* shall comply with all applicable laws*, regulations and nationally-ratified ${ }^{*}$ international treaties, conventions and agreements.

It is suggested that the term 'contracts' is added, as most, if not all, ecosystem services schemes will have contracts related to payments.

\subsection{The Organisation* shall demonstrate that the legal status* $^{*}$ of the Management Unit*, including tenure* and use rights*, and its boundaries, are clearly defined.}

\subsection{The Organisation* shall have legal* rights to operate in the Management Unit*, which fit the legal status $^{*}$ of the Organisation and of the Management Unit, and shall comply with the associated legal obligations in applicable national and local laws* and regulations and administrative requirements. The legal rights shall provide for harvest of products andlor supply of ecosystem services ${ }^{*}$ from within the Management Unit. The Organisation shall pay the legally prescribed charges associated with such rights and obligations.}

Improving forest management in tropical forests is one of the driving objectives behind certifying ecosystem services. Hence, in regard to criteria 1.2 and 1.3, it should be considered whether clearly defined de facto rights may be sufficient as de jure rights may be impossible to obtain in many tropical countries.

\subsection{The Organisation* shall comply with the applicable national laws*, local laws*, ratified* international conventions and obligatory codes of practice ${ }^{*}$, relating to the transportation and trade of forest products within and from the Management Unit*, andlor up to the point of first sale.}


It is suggested that criterion 1.5 should read '... relating to the transportation and trade of forest products and services...'

\section{Principle 2: Workers' rights and employment conditions}

The Organisation* shall maintain or enhance the social and economic well being of workers*.

This principle and its criteria apply in situations where sellers of the ecosystem service employ others, e.g. for monitoring purposes. In regard to criteria 2.4 below, it is worth considering whether wage standards should be based on the forest industry, for example, with regard to monitoring.

\subsection{The Organisation* shall pay wages that meet or} exceed minimum forest industry standards or other recognized forest industry wage agreements or living wages*, where these are higher than the legal minimum wages. When none of these exist, the Organisation shall through engagement ${ }^{*}$ with workers* develop mechanisms for determining living wages.

\section{Principle 3: Indigenous peoples' rights}

The Organisation* shall identify and uphold* indigenous peoples* legal and customary rights* of ownership, use and management of land, territories and resources affected by management activities.

\section{Principle 4: Community relations}

The Organisation* shall contribute to maintaining or enhancing the social and economic well being of local communities*.

Both of the principles above and their criteria are important to be included in standards for certification of ecosystem services. Free, Prior and Informed Consent (FPIC) is very important in regard to the social impact of management activities. Hence, in addition to the existing requirement to obtain FPIC, the compliance standards should perhaps include a clause about the process of obtaining FPIC (for FPIC related issues see section 4). In regard to these principles, the criterion of sharing benefits arising from the payments of ecosystem services could be added for certain situations such as where user rights are restricted to maintain or enhance service levels.

\section{Principle 5: Benefits from the forest}

The Organisation* shall efficiently manage the range of multiple products and services of the Management Unit* to maintain or enhance long-term economic viability* and the range of environmental and social benefits.

This is one of the key principles on which to build the standards to certify ecosystem services. The criterion 5.4 below mentions processing, which is not necessary for certifying ecosystem services but is relevant to ecosystem goods.

\subsection{The Organisation* shall use local processing, local} services and local value-added to meet the requirements of the Organisation where these are available, proportionate to scale, intensity and risk*. If these are not locally available, the Organisation shall make reasonable* attempts to help establish these services.

\subsection{The Organisation* shall demonstrate through its} planning and expenditures proportionate to scale, intensity and risk ${ }^{*}$, its commitment to long-term economic viability*.

Since the opportunity remains for other land use, the economic viability mentioned in criterion 5.5 is very important for the $(\mathrm{P}) \mathrm{ES}$ schemes to work and produce certifiable services in the long-term. Thus, economic viability is needed to forego opportunity costs that arise from, for example, not converting the forest area to other land use.

\section{Principle 6: Environmental values and impacts}

The Organisation* shall maintain, conserve and/or restore ecosystem services* and environmental values* of the Management Unit*, and shall avoid, repair or mitigate negative environmental impacts.

This principle is important, especially where timber production is combined with the provision of ecosystem services. Enhancement of services should be considered for inclusion in the above clause. If certain type of management action enhances service production and hence, brings additionality, a certified ecosystem services scheme becomes a possibility.

To make certification of ecosystem services simpler and cheaper, one option would be to exempt producers of certain ecosystem services (mainly water, biodiversity, carbon) from criteria 6.4.-6.5 and partially from 6.6 (see below). This would occur 
in cases where the identified impacts of management activities (criterion 6.2) would be minimal and if, in the case of biodiversity, it is not imperative to know exactly what species the forest contains. Exempting producers of services from species and habitat identification would save money and time.

6.2 Prior to the start of site-disturbing activities, the Organisation* shall identify and assess the scale, intensity and risk $k^{*}$ of potential impacts of management activities on the identified environmental values*.

\subsection{The Organisation* shall protect rare species*} and threatened species* ${ }^{*}$ and their habitats ${ }^{*}$ in the Management Unit* through conservation zones*, protection areas*, connectivity* andlor (where necessary) other direct measures for their survival and viability. These measures shall be proportionate to the scale, intensity and risk ${ }^{*}$ of management activities and to the conservation status and ecological requirements of the rare and threatened species. The Organisation shall take into account the geographic range and ecological requirements of rare and threatened species beyond the boundary of the Management Unit, when determining the measures to be taken inside the Management Unit.

\subsection{The Organisation* shall identify and protect} representative sample areas of native ecosystems andlor restore them to more natural conditions. Where representative sample areas do not exist, the Organisation shall restore a proportion of the Management Unit* to more natural conditions. The size of the areas and the measures taken for their protection or restoration shall be proportionate to the conservation status and value of the ecosystems at the landscape level, and the scale, intensity and risk ${ }^{*}$ of management activities.

\subsection{The Organisation* shall effectively maintain the} continued existence of naturally occurring native species and genotypes, and prevent losses of biological diversity*, especially through habitat management in the Management Unit*. The Organisation shall demonstrate that effective measures are in place to manage and control hunting, fishing, trapping and collecting.

Even if producers would be exempt from criterion 6.6 in regard to species existence, they should not be exempted from the requirement to manage and control hunting, fishing, trapping and collecting.

\section{Principle 7: Management planning}

The Organisation* shall have a management plan* consistent with its policies and objectives* and proportionate to scale, intensity and risks ${ }^{*}$ of its management activities. The management plan shall be implemented and kept up to date based on monitoring information in order to promote adaptive management* The associated planning and procedural documentation shall be sufficient to guide staff, inform affected stakeholders $^{*}$ and interested stakeholders* ${ }^{*}$ and to justify management decisions.

This principle and its criteria are applicable to certification of ecosystem services in its current form.

\section{Principle 8: Monitoring and assessment}

The Organisation* shall demonstrate that progress towards achieving the management objectives*, the impacts of management activities and the condition of the Management Unit* are monitored and evaluated proportionate to the scale, intensity and risk* of management activities, in order to implement adaptive management ${ }^{*}$.

This is another key principle on which to build the standards to certify ecosystem services. It is suggested that monitoring additionality, baseline/reference level, leakage/displacement and permanence is addressed.

\section{Principle 9: High conservation values}

The Organisation* shall maintain andlor enhance High Conservation Values* in the Management Unit* through applying the precautionary approach*.

This is another principle where exemption may be an option in areas where management actions cause only low disturbance. Other possibilities in regard to biodiversity monitoring were discussed earlier. In regard to cultural values (HCV 6, see below), access to cultural sites should be guaranteed. Appropriate compensation should be provided if any economic activities on the sites need to be limited.

HCV 6-Cultural values. Sites, resources, habitats and landscapes* of global or national cultural, archaeological or historical significance, andlor of critical cultural, ecological, economic or religious/sacred importance for the traditional cultures of local communities or indigenous peoples, identified through engagement with these local communities or indigenous peoples. 


\section{Principle 10: Implementation of management activities}

Management activities conducted by or for the Organisation* for the Management Unit* shall be selected and implemented consistent with the Organisation's economic, environmental and social policies and objectives* and in compliance with the Principles* and Criteria ${ }^{*}$ collectively.

The principle in itself is important and should be included in the standards for certification of ecosystem services. The criteria of this principle are especially relevant to ecosystem goods or when silvicultural activities take place in the management of the provision of ecosystem services, but also to afforestation and reforestation projects.

\subsubsection{FSC Standard for Chain of Custody Certification}

FSC Chain of Custody certification standard (FSC-STD-40-004) is relevant for certification of ecosystem services, specifically where this concerns buyers or traders of ecosystem goods and end products of services (e.g. water from certified watersheds) further down the production chain. It is the main standard that applies for the certification of all Chain of Custody operations and may be combined with complementary standards according to the scope of the organisation's certificate. The standard defines and addresses the basic elements of a Chain of Custody management system:

- Quality management: responsibilities, procedures and records

- Product scope: definition of product groups and outsourcing arrangements

- Material sourcing: specifications

- Material receipt and storage: identification and segregation

- Production control: control of quantities and determination of FSC claims

- Sales and delivery: invoicing and transport documentation

- Labelling: application of FSC labels on-product and labelling thresholds

The product type identification of ecosystem goods can fall back on the existing FSC Product Classification (FSC-STD-40-004a (V2-0 D1-0) EN) that specifies product codes for NTFPs.

The Chain of Custody standard requires a number of important commitments, including 1.5.1 that
"The organisation shall demonstrate its commitment to comply with the Values of FSC as defined in the 'Policy for the Association of Organisations with FSC (FSC-POL-01-004)" and 1.5.2 that, "The organisation shall declare not to be directly or indirectly involved in the following activities: a) Illegal logging or the trade in illegal wood or forest products; $b$ ) Violation of traditional and human rights in forestry operations; c) Destruction of high conservation values in forestry operations; d) Significant conversion of forests to plantations or non-forest use; e) Introduction of genetically modified organisms in forestry operations; f) Violation of any of the ILO Core Conventions, as defined in the ILO Declaration on Fundamental Principles and Rights at Work, 1998."

FSC's Standard for Company Evaluation of FSC Controlled Wood (FSC-STD-40-005 (Version 2-1) EN) provides useful guidance for developing a system to ensure that any ecosystem services and goods that are traded are legally harvested, do not violate traditional and civil rights, maintain high conservation values, do not involve conversion of forests to plantations or non-forest use and do not involve genetically modified species.

\subsubsection{Group Certification and SLIMF}

FSC group certification and small- and low-intensity managed forests (SLIMF) are important as a way for landowners to achieve certification, for example, for a watershed. Thus, they are briefly introduced here and aspects related to the development of compliance monitoring indicators for the certification of ecosystem services are discussed.

FSC group certification allows a group of forest owners to join together under a single FSC certificate. In principle, all group members need to comply with all of the requirements in the FSC standard. However, provision of ecosystem services, especially biodiversity and water, may be suitable for management at a group level.

The number of members is not limited, but the group has to be managed effectively and function according to FSC rules. A 'group entity' takes responsibility for ensuring compliance of group members with the certification standards; it may be a resource manager who also assumes responsibility for forest management activities.

Group certification can dramatically reduce the cost for each forest owner as all the costs involved 
in certification - such as report writing, travel costs of auditors, consulting with the public about the forest management - are shared among members. In addition, the auditors do not visit every single group member each year - only a sample. So cost per member is much lower than if each applied for a certificate. Group certification also usually means that group members get support from the group manager or from each other in complying with the FSC requirements for good forest management.

There are three major benefits to a group scheme: (1) the cost of certification for each member is much lower, bringing it within reach of almost all forest managers; (2) the group entity normally provides information and support to members in order to achieve certification and keep the certificate; and (3) there are better opportunities through the collective scale of production to access markets and obtain better prices.

Useful documents with regard to group certification include 'FSC-STD-30-005 V1-0 EN Group Entities FM Groups' and the above-mentioned 'FSCGUI-60-001 Guidance on the Interpretation of FSC Principles and Criteria'.

Certification for SLIMFs is streamlined to make certification more accessible and cost effective, while retaining the rigor of FSC certification processes. To that end, FSC provides consistent definitions of 'small' and 'low intensity' managed forests. A forest management unit qualifies as a 'small forest' if it is under $100 \mathrm{ha}$. A forest up to 1000 ha can also be deemed 'small' when it is formally proposed by the FSC-accredited national initiative concerned or if there is no national FSC initiative, a broad support is demonstrated by national stakeholders (exceptions listed in SLIMF Addendum). The forest is 'lowintensity managed' if: (1) the forest is being managed for the production of only NTFPs; (2) or the rate of harvesting timber is less than $20 \%$ of the mean annual increment (MAI) within the total production forest area of the unit; and (3) either the harvest from the total production forest area is less than 5000 cubic meters/year; or the average harvest from the total production forest is less than 5000 cubic meters/year during the certificate's period of validity as verified by harvest reports and surveillance audits.

Owners of small forests can also group together for a group certificate. Forest management groups can be a mix of SLIMF and non-SLIMF operations. SLIMF operations may benefit from the existing and well-established infrastructure of the non-SLIMFs operations; this will reduce individual costs and improve prices and incomes.

In addition to the core documents for forest management certification, such as the FSC Principles and Criteria (see above) and national FSC forest management standards, useful documents to explore with regard to SLIMF are: 'FSC STD 01003 V1 0 SLIMF Eligibility Criteria', 'FSC-STD-01-003a SLIMF Eligibility Criteria Addendum' and the 'FSCGUI-60-001 Guidance on the Interpretation of FSC Principles and Criteria to Take Account of Small Scale and Low Intensity'.

FSC-GUI-60-001 includes useful comments and advice for the development of compliance monitoring indicators for the certification of ecosystem services. It refers to version 4 of the FSC Principles and Criteria for Forest Stewardship, but the comments are nevertheless relevant for version 5 as well. Below the comments are in italics.

In regard to land tenure and use rights, it is noted that local communities and customary land-rights holders should be involved in defining the criteria and indicators.

Utmost care must be taken not to weaken the rights of local communities, customary rights holders and/ or indigenous peoples when modifying the standard to take account of scale and intensity. National Initiatives (NIs) and certifying bodies (CBs) are encouraged to distinguish between those categories of operations where the managers andlor owners are indigenous peoples, customary rights holders or local communities, and those where they are not. Equally, this approach shall apply to rights granted in concession agreements or felling licences. The overarching concept is that communities or indigenous peoples with ownership rights to the land and resources maintain control of the forest unless control is delegated with free and informed consent.

It is especially important in the definition of criteria and indicators for P2 that designated representatives of indigenous peoples, customary land-rights holders and local communities help to define the appropriate wording and appropriate verifiers.

The document also provides guidance on how to deal with de facto rights where no de jure rights exist. Improvement of forest management in the tropics, where documented legal land rights are often absent, is one of the driving objectives behind 
certifying ecosystem services. Thus, it is important for the certification standard to include de facto rights as well.

Legal documentation of forest use rights is not always available for traditional small/low intensity operations (e.g. non timber forest product harvesters who have had traditional usufruct rights). Verbal agreements, combined with a lack of forest use disputes can provide appropriate verification of compliance with this criterion.

Where traditional land use is determined by a tribal authority or other generally unregistered form of landownership by traditional peoples the NI/CB shallin coordination with the peoples concerned-determine an appropriate means of verifying long-term forest rights to the land.

Communities may also have disputes among themselves and, hence, require that these disputes are recognized.

Where a local community or indigenous people community is seeking certification, NIs/CBs should consider the possible case of disagreements over land tenure among such groups.

It is also important to consider indigenous people who may have access rights regardless of the owner or manager of the area.

Standards development groups should stress that P3 (on indigenous peoples' rights) applies even to situations where (non-indigenous) communities are managing their own lands, since there may be boundary or access issues with neighbours who are Indigenous Peoples. i.e. Don't assume that just because a local community is managing a forest that P3 doesn't apply. Check to see if there is a presence of Indigenous Peoples in the region in question.

It is especially important in the definition of criteria and indicators for $\mathrm{P} 3$, that designated representatives of indigenous peoples and customary land-rights holders help to define the appropriate wording and appropriate verifiers (more information in FSC-GUI-30-004 Guidance on Interpretation of FSC Principles 2 and 3).

There may be practical problems and challenges to consider, such as conditions related to workers' rights and requirements related to the ecology of species and conservation values.
Compliance with health and safety (H\&S) requirements is often a problem in small-or low-intensity operations in less-developed countries, e.g. in Papua New Guinea people are not used to wearing shoes while working in the forest, let alone safety boots; in Peru, Brazilian nut collectors may spend time in remote temporary camps with only rudimentary facilities which may nonetheless be similar to their own living conditions. Even compliance with existing legal requirements may be a problem for some traditional low-intensity operations.

For all criteria in P4 (on workers' rights), NIs/CBs are encouraged to identify specific indicators and verifiers for traditional forest uses and/or community-based forestry, if this is practiced or being developed in the region to which the standard applies. Traditional andl or community forestry may have their own regulations regarding access to employment, compensation, etc.

Annual harvesting levels may vary considerably. For some NTFP species, stock levels and growths are not well studied, and it is neither realistic nor appropriate to require low-intensity or small-operations to fund such research. Hence, for such instances, conservative harvesting levels and monitoring can be required.

For small-and low-intensity operations, the main challenge (cost and understanding) is likely to be identification and mapping of HCVFs at the FMU level. Once identified, low-intensity management should be adapted to comply with the precautionary approach.

Requirements related to small-scale forest operations and forests managed by indigenous people need to consider the circumstances as specified below.

In the case of very small forests, the forest operation generally generates little employment. The standard should not be overly demanding in terms of requirements for documentation if interviews and site evidence suggest no problems of compliance with this criterion.

For operations run by an indigenous peoples' organisation (tribe, community, etc.), and using only labour from their own community members their own internal regulations may be considered sufficient.

In regard to economic viability two important points are made.

Note that the different types of small-scale and lowintensity operations identified will be managed for very different objectives. It may not therefore be appropriate to ask all categories of forest operation to prove that 
they are striving toward economic viability, e.g. where certification is sought for an amenity woodland or where forest harvesting activities will have long-term subsidies sufficient to support the operations planned.

For group certification, rather than focus on the individual operations, the standard may require that the group entity is economically viable and/or has sufficient long-term stability to be able to offer the required services to its members.

The collective impact of the group should be taken into account in regard to ecosystem services. This is true, for example with respect to watershed in regard to the old principle 5.5 (Forest management operations shall recognize, maintain and, where appropriate, enhance the value of forest services and resources such as watersheds and fisheries) and to the old principle 6 on environmental impact.

This [i.e. principle 5.5] may be especially important when dealing with groups of small forests, which may collectively have a considerable impact on a watershed or resource. Standards writing groups may consider specifying stronger indicators for groups.

Many of the categories of low-intensity or small-scale forest operations should, by definition, have a low risk of severe environmental impacts. However, all forests are part of an existing landscape, and some consideration needs to be given to this when management is determined.

For this reason, the indicators used may vary considerably: specifying different types of assessments required.

Baseline information of forest structure and of preintervention forest conditions shall be documented so that possible negative environmental impacts are identified and minimised through writing and implementing a management plan; for certain categories of operations it may be appropriate to link 6.1 with 7.1, i.e. to require that the simple management plan includes a simple environmental impact assessment.

In the case of group certificates, the need for conservation zones and protection areas can be dealt with collectively at the group level, or by proven off-site benefits from the forest management being undertaken. Group entities may also be required to seek information from the relevant state or national government wildlifelfaunal habitat department regarding rare, threatened or endangered species and to incorporate this information into the management plan.

As the provision of ecosystem services will require no harvesting, the management plan can be kept very simple. There are also other conditions that will affect a management plan as exemplified below.

NIs should define a set of very basic requirements for management plans of small-and low-intensity operations; in forests where no felling, regeneration or road/trail construction is planned, an even simpler document may be adequate.

Where land tenure is shorter than full rotation, it may be more appropriate to describe the desired future condition of individual stands (or perhaps the entire forest for low intensity) in terms of stand age andl or size class, and to outline a harvesting scheme (e.g. area or volume of harvest and frequency of harvest) that will result in the desired forest structure which does not inhibit the adjacent and surrounding landscape ecosystem dynamics, integrity and high conservation values.

The requirements for management plans will be further simplified for the harvesting of NTFPs and for forest use where no harvesting is planned (e.g. watershed conservation, recreation)

With very few exceptions there must be a written management plan for the forest. There will be very few examples where a written management plan is not feasible: even in areas where literacy levels are low among forest managers they may be supported by a group manager or an $N G O$ in recording their intentions. However, where NIs/CBs think it appropriate so as not to create unnecessary barriers to participation by traditional communities, requirements can be simplified and may include some verbal explanations.

In regard to monitoring, guidance should be given and criteria adapted as exemplified below in regard to criterion 8.2.

8.2 Forest management should include the research and data collection needed to monitor, at a minimum, the following indicators:

a) Yield of all forest products harvested.

b) Growth rates, regeneration and condition of the forest. 
c) Composition and observed changes in the flora and fauna.

d) Environmental and social impacts of harvesting and other operations.

e) Costs, productivity and efficiency of forest management.

The list of indicators contained in Criterion 8.2 may be beyond the needs and ability of most small-and low- intensity operations to monitor and be inappropriate to require this of small-and low-intensity operations. This particularly applies to d) and e).

NIs should define a set of very basic requirements for monitoring of small-and low-intensity operations.

As the comments show, it will be possible to modify and simplify the existing FSC forest management standards to develop certification of ecosystem services. 


\section{References}

Anadón JD, Giménez A, Ballestar R and Perez I. 2009. Evaluation of local ecological knowledge as a method for collecting extensive data on animal abundance. Conservation Biology 23:617-25.

Andrianandrasana HT, Randriamahefasoa J, Durbin J, Lewis RE and Ratsimbazafy JH. 2005. Participatory ecological monitoring of the Alaotra wetlands in Madagascar. Biodiversity and Conservation 4:2757-74.

Anil CN. 2004. Participatory 3-dimensional modeling for ecological monitoring in mountainous areas. Nepal: ICIMOD/IFAD Partnership Programme.

Anonymous. Practical manual. Water quality assessment: macroinvertebrate as biomonitoring indicator.

Asquith N and Wunder S, eds. 2008 Payments for watershed services: The Bellagio Conversations. Santa Cruz de la Sierra, Bolivia: Fundación Natura Bolivia.

Bagby K, Brown B, Chapp S and Hunter J. 2003. Sharing stewardship of the harvest: Building capacity among low income non-timber forest product harvesters. Taylorsville, USA: Pacific West Community Forestry Center and Forest Community Research.

Basuki I 2011. Formulasi pemantauan partisipatif kualitas lahan dan air untuk program penatagunaan lahan di Laos [MSc thesis]. Bogor, Indonesia: Institut Pertanian.

Becker CD, Agreda A, Astudillo E, Constantino $\mathrm{M}$ and Torres P. 2005. Community-based monitoring of fog capture and biodiversity at Loma Alta, Ecuador enhance social capital and institutional cooperation. Biodiversity and Conservation 14:2695-707.

Bennun L, Matiku P, Mulwa R, Mwangi S and Buckley P. 2005. Monitoring important bird areas in Africa, towards a sustainable and scaleable system. Biodiversity and Conservation 14:2575-90.

Bird DN, Pena N, Schwaiger H and Zanchi G 2010. Review of existing methods for carbon accounting. Bogor, Indonesia: Center for International Forestry Research (CIFOR).

Blackman A and Rivera J. 2010. Environmental certification and the Global Environment
Facility: A STAP advisory document. Nairobi, Kenya: UNEP.

Brito B, Davis C, Daviet F, Micol L, Nakhooda $S$ and Thuault A. 2009. The governance of forests toolkit (version 1): A draft framework of indicators for assessing governance of the forest sector. Washington, DC: World Resources Institute (WRI).

Bruijnzeel LA. 2004. Hydrological functions of tropical forests: not seeing the soil for the trees? Agriculture, Ecosystems and Environment 104:185-228.

Carney D, ed. 1998. Sustainable Rural Livelihoods: What contribution Can We Make? London: Department for International Development (DFID).

Chamberlain J, Bush R and Hammett AL. 1998. Non-timber forest products. The other forest products. Forest Products Journal 48:10-19.

Chapagain AK and Hoekstra AY. 2011. The blue, green and grey water footprint of rice from production and consumption perspectives. Ecological Economics 70: 49-58.

Chapman D, ed. 1992. Water Quality Assessments: $A$ Guide to Use of Biota, Sediments And water in Environmental Monitoring, 2nd ed. London: F \& FN Spon,.

Colfer CJP, Prabhu R, Günter M, McDougall C, Porro NM and Porro R. 1999. Who Counts Most? Assessing Human Well-being in Sustainable Forest Management. Bogor, Indonesia: Center for International Forestry Research (CIFOR).

HCV Consortium. 2009. Toolkit for Identification of High Conservation Values in Indonesia. Jakarta, Indonesia: HCV Consortium.

Coria J and Calfucura E. 2012. Ecotourism and the development of indigenous communities: The good, the bad and the ugly. Ecological Economics 73:47-55.

Cronkleton P, Keating RE and Evans K. 2007. Helping village stakeholders monitor forest benefits in Bolivia. In Guijt I, ed. Negotiated Learning: Collaborative Monitoring in Forest Resource Management. Washington, DC: Resources for the Future. 58-65.

Cunha dos Santos M. 2002. Adaptive collaborative management in Acre: a case study of the agroextractive project Porto Dias, Acre, Brazil. 
Gainesville, Florida: PESACRE/University of Florida/CIFOR.

Danielsen F, Balete DL, Poulsen MK, Enghoff M, Nozawa CM and Jensen AJ. 2000. A simple system for monitoring biodiversity in protected areas of a developing country. Biodiversity and Conservation 9:1671-705.

Danielsen F, Burgess ND and Balmford A. 2005. Monitoring matters: examining the potential of locally-based approaches. Biodiversity and Conservation 14:2507-42.

Danielsen F, Mendoza MM, Tagtag A, Alviola PA, Balete DS, Jensen AE, Enghoff $M$ and Poulsen MK. 2007. Increasing conservation management action by involving local people in natural resource monitoring. Ambio 36:566-70.

Danielsen F, Mendoza MM, Tagtag A, Alviola PA, Balete DS, Jensen AE, Enghoff $M$ and Poulsen MK et al. 2009. Local participation in natural resource monitoring: a characterization of approaches. Conservation Biology 23:31-42.

De Gryze S and Durschinger L. 2009. Payment for ecosystem services: developing forest carbon projects in Nepal. A case study under TRANSLINKS. Washington, DC: EnterpriseWorks/VITA.

DeWan AA and Zipkin EF. 2010. An integrated sampling and analysis approach for improved biodiversity monitoring. Environmental Management 45:1223-30.

Donovan RZ. 2000. Observations on equity after ten years of SmartWood certification. Paper to the Second Annual FSC Conference, November 2000, Oaxaca, Mexico. Accessed 9 September 2010. http://74.125.155.132/ scholar?q=cache:n_3Uhk7MCAoJ:scholar. google.com/+NTFP+certification\&hl=en\&as_ $\mathrm{sdt}=2000$.

Ecosecurities. 2009. The forest carbon offsetting survey 2009. Dublin, Ireland: Ecosecurities.

Emerton L and Bos E. 2004. Value: Counting ecosystems as an economic part of water infrastructure. Gland, Switzerland and Cambridge, UK: International Union for Conservation of Nature (IUCN).

Estrada M. 2011. Standards and Methods Available for Estimating Project-level REDD+CARBON benefits: Reference Guide for Project Developers. Bogor, Indonesia: Center for International Forestry Research (CIFOR).

Evans K, de Jong W, Cronkleton P, Sheil P, Lynam T, Kusumanto T and Colfer CJP. 2006. Guide to Participatory Tools for Forest Communities. Bogor, Indonesia: Center for International Forestry Research (CIFOR).
Fisher J. 2012. No pay, no care? A case study exploring motivations for participation in payments for ecosystem services in Uganda. Oryx 46:45-54.

Fröde AMC and Masara C. 2007. Community-based Ecological Monitoring. Manual for Practitioners. Harare, Zimbabwe: SAFIRE - Southern Alliance for Indigenous Resources.

Frost PGH and Bond I. 2008. The CAMPFIRE programme in Zimbabwe: payments for wildlife services. Ecological Economics 65:776-87.

[FSC] Forest Stewardship Council. 2009. FSC impacts and outcomes: Extracts from FSC literature review 2009. Accessed 10th January 2012. http://www.fsc.org/fileadmin/web-data/ public/document_center/publications/FSC_ Policy_Series/Impacts_lit_review_summary_ EN.PDF.

Gaidet N, Fritz H and Nyahma CA. 2003. Participatory counting method to monitor populations of large mammals in non-protected areas: A case study of bicycle counts in the Zambezi Valley, Zimbabwe. Biodiversity and Conservation 12:1571-85.

Gaidet-Drapier N, Fritz H, Bourgarel M, Renaud P, Poilecot P, Chardonnet P, Coid C, Poulet D and Le Bel S. 2005. Cost and efficiency of large mammal census techniques: comparison of methods for participatory approach in a communal area, Zimbabwe. Biodiversity and Conservation 5:735-54.

Garcia CA and Lescuyer G. 2008. Monitoring, indicators and community based forest management in the tropics: Pretexts or red herrings? Biodiversity and Conservation 17:1303-17.

Garcia C, Pain-Orcet M, Dubuc S, Konerira N, Murali KS, Depommier D, Kushalappa CG and Seen DL. 2004. Indicators for Management of Natural Resources. Case Study: Community Based Forest Management in the Western Ghats (India). Montpellier, France: CIRAD.

Ghate R and Nagendra H. 2005. Role of monitoring in institutional performance: forest management in Maharashtra, India. Conservation and Society 3:509-32.

Goetz SJ, Baccini A, Laporte NT, Johns T, Walker W, Kellndorfer J, Houghton RA and Sun M. 2009. Mapping and monitoring carbon stocks with satellite observations: A comparison of methods. Carbon Balance and Management 4:2. doi:10.1186/1750-0680-1184-1182.

Goldberg J. 2007. Economic valuation of watershed systems: A tool for improved water resource 
management. Paper to VI Inter-American dialogue on water resource management. Guatemala City, Guatemala. 15 August 2007. Gomani MC, Dietrich O, Lischeid G, Mahoo H, Mahay F, Mbilinyi B and Sarmett J. 2010. Establishment of a hydrological monitoring network in a tropical African catchment: An integrated participatory approach. Physics and Chemistry of the Earth 35:648-56.

Green RE, Balmford A, Crane PR, Mace GM, Reynolds JD and Turner RK 2005. A framework for improved monitoring of biodiversity: Response to the World Summit on Sustainable Development. Conservation Biology 19: 56-65.

Green Resources. 2010. Reforestation in grassland areas of Uchindile, Kilombero, Tanzania and Mapanda, Mufindi, Tanzania. VCS Monitoring Report. 1 January 2002-30 November 2008. Dar es Salaam, Tanzania: Green Resources.

Gross-Camp ND, Martin A, McGuire S, Kebede B and Munyarukaza J. 2012. Payments for ecosystem services in an African protected area: Exploring issues of legitimacy, fairness, equity and effectiveness. Oryx 46:24-33.

Guariguata MR and Balvanera P. 2009.

Tropical forest service flows: improving our understanding of the biophysical dimension of ecosystem services. Forest Ecology and Management 258:1825-9.

Hamilton C, Rai RK, Shrestha RB, Maharian M, Rasaily L and Hood S. 2001. Exploring visions: Self-monitoring and evaluation processes within the Nepal-UK community forestry project. In Estrella M, ed. Learning from Change: Issues and Experiences in Participatory Monitoring and Evaluation. Ottawa, Canada: International Development Research Centre (IDRC). 15-31.

Heink U and Kowarik I. 2010. What criteria should be used to select biodiversity indicators? Biodiversity and Conservation 19:3769-97.

Holck MH. 2008. Participatory forest monitoring: an assessment of the accuracy of simple costeffective methods. Biodiversity and Conservation 17:2023-36.

[IUCN] International Union for Conservation of Nature. 2011. IUCN Red list of threatened species version 2010.2. Accessed 6 January 2012. www.iucnredlist.org.

Jeanes K, van Noordwijk M, Joshi L, Widayati A and Farida LB. 2006. Rapid Hydrological Appraisal in the Context of Environmental Service Rewards. Bogor, Indonesia: World Agroforestry Centre, Southeast Asia Regional Center.
Johnson N, White A and Perrot-Maitre D. 2001. Developing markets for water services from forests: issues and lessons for innovators. 26p. Washington, DC: World Resources Institute, Forest Trends, The Katoomba Group.

Katoomba Group and UNEP. 2008. Payments for Ecosystem Services. Getting Started: A Primer. Forest Trends, The Katoomba Group and the UN Environment Programme.

Kiss A. 2004. Is community-based ecotourism a good use of biodiversity conservation funds? Trends in Ecology and Evolution 19:232-6.

Kongo VM, Kosgei JR, Jewitt GPW and Lorentz SA. 2007. Establishment of a catchment monitoring network through a participatory approach in a small rural catchment in South Africa. Hydrology and Earth System Sciences Discussions 4:3793-837.

Kosoy N, Martinez-Tuna M, Muradian R and Martinez-Alier J. 2007. Payments for environmental services in watersheds: insights from a comparative study of three cases in Central America. Ecological Economics 61:446-55.

Kusumanto T. 2007. Learning to monitor political processes for fairness in Jambi, Indonesia. In Guijt I, ed. Negotiated Learning: Collaborative Monitoring in Forest Resource Management. Washington, DC: Resources for the Future. 124-134.

Landell-Mills N and Porras IT. 2002. Silver Bullet or Fools' Gold? A Global Review of Markets for Forest Environmental Services and their Impacts on the Poor. Instruments for Sustainable Private Sector Forestry Series. London: International Institute for Environment and Development.

Lasco RD, Villamor G, Pulhin FB, Catacutan D and Bertomeu M. 2008. From principles to numbers: Approaches in implementing payments for environmental services (PES) in the Philippines. Advances in Agroforestry 5:379-91.

Law E, Dargusch PJ, Thomas S, Meijaard E and Wilson KA. In press. Using modularity to manage complexity in international forest carbon policy. Nature Climate Change.

Lawrence A, Paudel K, Barnes R and Malla Y. 2006. Adaptive value of participatory biodiversity monitoring in community forestry. Environmental Conservation 33:325-34.

Lawrence A, Kinhal G, Luintel H, Molteno S and Gillett S. 2008. Participatory Science for Sustainable Wild Harvests: A Methods Handbook. Oxford, UK: ForestAction, Foundation for the 
Revitalisation of Local Health Traditions, and DFID Forest Research Programme, University of Oxford.

Le Tellier V, Carrasco A and Asquith N. 2009. Attempts to determine the effects of forest cover on stream flow by direct hydrological measurements in Los Negros, Bolivia. Forest Ecology and Management 258:1881-8.

Levia DF, Carlyle-Moses D and Tanaka T, eds. 2011. Forest Hydrology and Biogeochemistry: Synthesis of Past Research and Future Directions. Dordrecht, Heidelberg, London, New York: Springer.

Losos EC and Leigh JEG, eds. 2004. Tropical Forest Diversity and Dynamism: Findings from a Largescale Plot Network. Chicago, IL, USA: University of Chicago Press.

Lynam T, de Jong W, Sheil D, Kusumanto T and Evans K. 2007. A review of tools for incorporationg community knowledge, preferences, and values into decision making in natural resources management. Ecology and Society 12:5.

MacDicken K. 1997. A Guide to Monitoring Carbon Storage in Forestry and Agroforestry Projects. Arlington, US: Winrock International.

Maitima JM and Olson JM. 2001. Guide to field methods for comparative site analysis for the land use change, impacts and dynamics project. Working Paper, Vol. 15. Land Use Change, Impacts and Dynamics Project, Nairobi, Kenya.

Marx A and Cuypers D. 2010. Forest certification as a global environmental governance tool: What is the macro-effectiveness of the Forest Stewardship Council? Regulation \& Governance 4:408-34.

McDougall C. 2001. Assessing the sustainability of community managed forests. IDRC Final Technical Report. Bogor, Indonesia: Center for International Forestry Research (CIFOR).

Meidinger E, Elliott C and Oesten G. 2003. The fundamentals of forest certification. In Meidinger E, Elliott C and Oesten G, eds. Social and Political Dimensions of Forest Certification. Remagen-Oberwinter, Germany: Forstbuch Verlag. 3-26.

Meijaard E and Sheil D. 2012. The dilemma of green business in tropical forests: How to protect what it cannot identify. Conservation Letters 5:342-8.

Meijaard E, Sheil D, Guariguata MR, Nasi R, Sunderland T and Putzel L. 2011. Report on barriers and constraints to ecosystem services certification. Occasional Paper 66, Bogor, Indonesia: Center for International Forestry Research (CIFOR).
Mermet L, Billé R, Leroy M, Narcy J-B and Pouxe X. 2005. L'analyse strategique de la gestion environnementale: un cadre théorique pour penser l'efficacité en matière environment. Natures Sciences Sociétés 13:127-37.

Miranda, M., Porras, I.T. and Moreno, M.L. 2003 The Social Impacts of Payments for Environmental Services in Costa Rica. A Quantitative Field Survey and Analysis of the Virilla Watershed. London: International Institute for Environment and Development.

Mueller JG, Assanou IH, Dan Guimbo I and Almedom AM. 2009. Evaluating rapid participatory rural appraisal as an assessment of ethnoecological knowledge and local biodiversity patterns. Conservation Biology 24:140-50.

Murthy, I.K., Hegde, G.T., Sudha, P. and Ravindranath, N.H. 2006 Methodological issues in developing a community forestry greenhouse gas emissions mitigation project in Mancherial forest division of Andhra Pradesh, India. Environmental Science and Policy 9:525-37.

Nanyunja RK. 2006. The role of indigenous knowledge in biodiversity assessment and monitoring: A case study in Uganda. In Fort Collins, USA: US Department of Agriculture, Forest Service, Rocky Mountain Research Station. 543-9.

Nelson E, Mendoza G, Regetz J, Polasky S, Tallis H, Cameron DR, Chan KMA, Daily GC, Goldstein J, Kareiva PM et al. . 2009 Modeling multiple ecosystem services, biodiversity conservation, commodity production, and tradeoffs at landscape scales. Frontiers in Ecology and the Environment 7:4-11.

Noerdjito M and Maryanto I, eds. 2007. Jenis-jenis hayati yang dilindungi perundang-undangan Indonesia. Cibinong, Indonesia: Balitbang Zoologi (Museum Zoologicum Bogoriense), Puslitbang-LIPI, and The Nature Conservancy.

Noss AJ, Oetting I and Leny Cuellar R. 2005. Hunter self-monitoring by the IsosenoGuaranı' in the Bolivian Chaco. Biodiversity and Conservation 14:2679-93.

Nussbaum RSM. 2005. Forest Certification Handbook, 2nd edn. London: Earthscan.

Ojha $\mathrm{H}$ and Bhattarai B. 2003. Learning to manage a complex resource: a case of NTFP assessment in Nepal. International Forestry Review 5:118-27.

Ojha H, Paudel K and Neupane H. 2003. Biodiversity assessment for whom? Issues, perspectives and lessons from community forestry in Nepal. A discussion note. Kathmandu, Nepal: Forest Resources Studies and Action Team. 
Pagiola S, Arcenas A and Platais G. 2005. Can payments for environmental services help reduce poverty? An exploration of the issues and the evidence to date from Latin America. World Development 33:237-53.

Paoli GD, Wells PL, Meijaard E, Struebig MJ, Marshall AJ, Obidzinski K, Tan A, Rafiastanto A, Yaap B, Slik FJW et al. 2010 Biodiversity conservation in the REDD. Carbon Balance and Management 5.

Poulsen MK and Luanglath K. 2005. Projects come, projects go: lessons from participatory monitoring in southern Laos. Biodiversity and Conservation 14:2591-610.

Purnomo H, Mendoza GA and Prabhu R. 2005. Analysis of local perspectives on sustainable forest management: an Indonesian case study. Journal of Environmental Management 74:111-26.

Ridoutt BG and Pfister S. 2010. A revised approach to water footprinting to make transparent the impacts of consumption and production on global freshwater scarcity. Global Environmental Change-Human \& Policy Dimensions 20:113-20.

Ritchie B, McDougall C, Haggith M and Burford de Oliveira N. 2000. Criteria and Indicators of Sustainability in Community Managed Forest Landscapes: An Introductory Guide. Bogor, Indonesia: Center for International Forestry Research (CIFOR).

Roy SB. 2004. Participatory vegetation monitoring: examples from West Bengal. In Bahuguna VK, Capistrano D and Saigal S, eds. Root to Canopy: Regenerating Forests through Community-State Partnerships. New Delhi, India: Winrock International India/Commonwealth Forestry Association-India Chapter. 267-73.

Salafsky N and Wollenberg E. 2000. Linking livelihoods and conservation: a conceptual framework and scale for assessing the integration of human needs and biodiversity. World Development 28:1421-38.

Salafsky N, Cauley H, Balachander G, Cordes B, Parks J, Margoluis C, Bhatt S, Encarnacion C, Russell D and Margoluis R. 2001. A systematic test of an enterprise strategy for communitybased biodiversity conservation. Conservation Biology 15:1585-95.

Schreckenberg K, Camargo I, Withnall K, Corrigan C, Franks P, Roe D, Scherl LM and Richardson V. 2010. Social assessment of conservation initiatives: A review of rapid methodologies. In Natural Resource Issues, Vol. 22. London:
International Institute for Environment and Development (IIED).

Shanley P and Stockdale M. 2008. Traditional knowledge, forest management, and certification: A reality check. Forests, Trees and Livelihoods 18:55-68.

Shanley P, Pierce AR, Laird SA and Guillen A, eds. 2002. Tapping the Green Market: Certification and Management of Non-timber Forest Products. London: Earthscan Publications.

Shanley P, Pierce AR, Laird S and Robinson D. 2008. Beyond Timber: Certification and Management of Non-timber Forest Products. Bogor, Indonesia: Center for International Forestry Research (CIFOR).

Simula M, Astana S, Ishmael R, Santana EJ and Schmidt ML. 2004. Report on financial cost-benefit analysis of forest certification and implementation of phased approaches. Yokohama, Japan: International Tropical Timber Organization (ITTO).

Skutsch MM, McCall MK, Karky B, Zahabu E and Peters-Guarin G. 2009. Community measurement of carbon stock change for REDD. Working Paper 156. Rome: Food and Agricultural Organization of the United Nations (FAO), Forest Resources Assessment Programme.

Sommerville MM, Milner-Gulland EJ and Jones JPG. 2011. The challenge of monitoring biodiversity in payment for environmental service interventions. Biological Conservation 144:2832-41.

Sprang P. 2001. Aspects of quality assurance under the certification schemes FSC and PEFC. Freiburg, Germany: Albert-Ludwigs-Universität Forstwissenschaftlichen Fakultät.

Steinmetz R, Chutipong W and Seuaturien N. 2006. Collaborating to conserve large mammals in Southeast Asia. Conservation Biology 20:1391-401.

Stockdale M. 2005. Steps to Sustainable and Community-based NTFP Management. Quezon City, Philippines: NTFP Exchange Programme for South and Southeast Asia.

Stockdale, M and Corbett, J.M.S. 1999 Participatory inventory: A field manual written with a special reference to Indonesia. Tropical Forestry Papers 38.

Stuart-Hill G, Diggle R, Munali B, Tagg J and Ward D. 2005. The Event Book System: A community-based natural resource monitoring system from Namibia. Biodiversity and Conservation 14:2611-31. 
Subedi BP, Pandey SS, Pandey A, Rana EB, Bhattarai

S, Banskota TR, Charmakar S and Tamrakar

R. 2010. Forest Carbon Stock Measurement:

Guidelines for Measuring Carbon Stocks in

Community-managed Forests. Kathmandu,

Nepal: Asia Network for Sustainable Agriculture and Bioresources (ANSAB), Federation of Community Forest Users, Nepal (FECOFUN),

International Centre for Integrated Mountain

Development (ICIMOD) and Norwegian

Agency for Development Cooperation

(NORAD).

Topp-Jorgensen E, Poulsen MK, Lund JF and Massao JF. 2005. Community-based monitoring of natural resource use and forest quality in montane forests and miombo woodlands of Tanzania. Biodiversity and Conservation 14:2653-77.

[UNDESA] UN Department of Economic and Social Affairs. 2005. Free, Prior Informed Consent and beyond: the experience of IFAD. In International Workshop on Methodologies Regarding Free Prior and Informed Consent and Indigenous Peoples. New York: UN Department of Economic and Social Affairs.

van der Meer PJ, Schmerbeck J, Hooda A, Bairaktari C, Bisht NS, Gusain MS, Singh CJ, Naithani A, Saxena A, Olsthoorn AFM and de Groot RS. 2007 Assessment of ecosystem goods and services from forests in India, The Netherlands and Germany. In NETworking FOrest Plantations in a Crowded World: Optimising Ecosystem Services through Improved Planning and Management, Vol. NETFOP01. 134p.

van Noordwijk M, Leimona B, Tomich TP, Velarde SJ, Kallesoe M, Sekher M and Swallow B. 2007. Criteria and indicators for environmental service compensation and reward mechanisms: realistic, voluntary conditional and pro-poor. CES Scoping Study Issue Paper no. 2. ICRAF Working Paper 37. Nairobi, Kenya.
Van Rijsoort J and Jinfeng Z. 2005. Participatory resource monitoring as a means for promoting social change in Yunnan, China. Biodiversity and Conservation 14:2543-73.

Verplanke JJ and Zahabu E, eds. 2009. A Field Guide for Assessing and Monitoring REDUCED forest Degradation and Carbon Sequestration by Local Communities. Enschede, The Netherlands: Project team KYOTO: Think Global, Act Local. Available at: www.communitycarbonforestry.org Vogt KA, Larson BC, Vogt DJ, Gordon JC, Fanzeres A, O'Hara JL and Palmiotto PA. 2000. Issues in forest certification. In Vogt KA, Larson BC, Gordon JC, Vogt DJ, Fanzeres A, eds. Forest Certification Roots, Issues, Challenges and Benefits. Boca Raton, London, New York, Washington, DC: CRC Press LLC. 1-10.

Wendland KJ, Honzak M, Portela R, Vitale B, Rubinoff S and Randrianarisoa J. 2010. Targeting and implementing payments for ecosystem services: Opportunities for bundling biodiversity conservation with carbon and water services in Madagascar. Ecological Economics 69:2093-107.

Wertz-Kanounnikoff S. 2008. Monitoring Forest Emissions: A Review of Methods. Bogor, Indonesia: Center for International Forestry Research (CIFOR).

Widman, P., Baral, H.S. and Eaton, M. 2003 Development of participatory biodiversity monitoring concept and metholodology. Churia Forest Development Project PN 2001.2173.1

Wilson MA and Howarth RB. 2002. Discourse-based valuation of ecosystem services: establishing fair outcomes through group deliberation. Ecological Economics 41:431-43.

Wollenberg E, Edmunds D and Buck L. 2000. Anticipating Change: Scenarios as a Tool For adaptive Forest Management. Bogor, Indonesia: Center for International Forestry Research (CIFOR). 


\section{Annexes}

\section{Annex 1. Guidance to participatory monitoring}

The following table provides a quick reference to guide participatory monitoring. Further monitoring guidance can be found in Annex 2.

\begin{tabular}{|c|c|c|}
\hline Type of measurement & Methods & Citation \\
\hline \multicolumn{3}{|l|}{ Biodiversity } \\
\hline \multicolumn{3}{|l|}{ Species } \\
\hline \multirow[t]{2}{*}{ Animals } & Counts & $\begin{array}{l}\text { Timed species counts (Widman et al. 2003; } \\
\text { Maitima and Olson 2001) }\end{array}$ \\
\hline & & $\begin{array}{l}\text { Water point counts (Gaidet-Drapier et al. } \\
\text { 2005); Mist nets and strip counts (Becker et al. } \\
\text { 2005) }\end{array}$ \\
\hline Animals & Multi-species inventory & DeWan and Zipkin 2010 \\
\hline \multirow[t]{9}{*}{ Animals, plants } & Transects & General method \\
\hline & & (Danielsen et al. 2005); \\
\hline & & Transects by canoe \\
\hline & & (Andrianadrasana et al. 2005); \\
\hline & & Transects by bicycle \\
\hline & & (Gaidet and Nyahma 2003); \\
\hline & & Car counts, bicycle counts, and foot counts \\
\hline & & (Gaidet-Drapier et al. 2005; \\
\hline & & Shanley and Stockdale 2008) \\
\hline Animals, plants & Local ecological knowledge & $\begin{array}{l}\text { Nayunja 2006; Anadón et al. 2009; Mueller et } \\
\text { al. } 2009\end{array}$ \\
\hline Fish & Fish catches & $\begin{array}{l}\text { Andrianadrasana et al. 2005; Poulsen and } \\
\text { Luanglath } 2005\end{array}$ \\
\hline Mammals & $\begin{array}{l}\text { Workshops integrating ranking } \\
\text { exercises to develop a spatially explicit } \\
\text { picture of long-term trends in the } \\
\text { abundance of mammal species and } \\
\text { compare species-specific causes for } \\
\text { declines. }\end{array}$ & Steinmetz et al. 2006 \\
\hline Mammals & Camera traps & Poulsen and Luanglath 2005 \\
\hline Plants & Vegetation plots & Roy 2004 \\
\hline $\begin{array}{l}\text { Species as well as forest } \\
\text { condition }\end{array}$ & $\begin{array}{l}\text { Standardized recording of routine } \\
\text { observations (field diary) }\end{array}$ & $\begin{array}{l}\text { Danielsen et al. 2000; Poulsen and Luanglath } \\
2005\end{array}$ \\
\hline \multicolumn{3}{|l|}{ Habitat } \\
\hline \multirow[t]{2}{*}{ Forest condition } & Forest walks & $\begin{array}{l}\text { Van Rijsoort and Jinfeng 2005; Lawrence et al. } \\
2006\end{array}$ \\
\hline & Daily patrols & Ghate and Nagendra 2005 \\
\hline \multirow[t]{2}{*}{ Forest resources } & Resource maps & Lawrence et al. 2006 \\
\hline & The Event Book system & Stuart-Hill et al. 2005 \\
\hline
\end{tabular}


Annex 1. Continued

\begin{tabular}{|c|c|c|}
\hline Type of measurement & Methods & Citation \\
\hline Forest degradation & Fixed point photography & $\begin{array}{l}\text { Danielsen et al. 2000; Poulsen and Luanglath } \\
2005\end{array}$ \\
\hline \multicolumn{3}{|l|}{ Threats } \\
\hline \multirow[t]{4}{*}{ Resource use } & $\begin{array}{l}\text { Participatory 3-Dimensional Modeling } \\
\text { (P3DM) }\end{array}$ & Anil 2004 \\
\hline & $\begin{array}{l}\text { Driver-Pressure-State-Impact- } \\
\text { Response (DPSIR) framework }\end{array}$ & Green et al. 2005 \\
\hline & $\begin{array}{l}\text { Pressure-State-Response monitoring } \\
\text { framework }\end{array}$ & Bennun et al. 2005 \\
\hline & Ecological monitoring & Fröde and Masara 2007 \\
\hline \multicolumn{3}{|l|}{ Positive actions } \\
\hline & $\begin{array}{l}\text { Hunter self-monitoring with } \\
\text { community monitors' assistance }\end{array}$ & Noss et al. 2005 \\
\hline & Wildlife trade monitoring & Poulsen and Luanglath 2005 \\
\hline \multicolumn{3}{|l|}{ Carbon } \\
\hline $\begin{array}{l}\text { Above-ground tree and } \\
\text { sapling biomass }\end{array}$ & & $\begin{array}{l}\text { Murthy et al. 2006; Verplanke and Zahabu } \\
\text { 2009; Subedi et al. } 2010\end{array}$ \\
\hline Below-ground biomass & & Murthy et al. 2006; Subedi et al. 2010 \\
\hline Herb and grass biomass & & Subedi et al. 2010 \\
\hline Leaf litter & & Subedi et al. 2010 \\
\hline Soil organic carbon & & Subedi et al. 2010 \\
\hline Total carbon stock density & & Skutsch et al. 2009; Subedi et al. 2010 \\
\hline \multicolumn{3}{|l|}{ Non-timber forest products } \\
\hline Animal population survey & & Stockdale 2005 \\
\hline $\begin{array}{l}\text { Delineation of the } \\
\text { management zones }\end{array}$ & & Ojha and Bhattarai 2003; Stockdale 2005 \\
\hline Demography & & Stockdale 2005 \\
\hline Forest products & User-developed self-monitoring & Hamilton et al. 2001 \\
\hline Harvesting & Harvesting techniques & Ojha and Bhattarai 2003; Lawrence et al. 2008 \\
\hline Inventories & & $\begin{array}{l}\text { Stockdale and Corbett 1999; Ojha and } \\
\text { Bhattarai 2003; Widman et al. } 2003\end{array}$ \\
\hline Recovery time & & Stockdale 2005 \\
\hline Regeneration & & Stockdale 2005 \\
\hline $\begin{array}{l}\text { Social, cultural and } \\
\text { environmental dimensions } \\
\text { of NTFPs harvesting }\end{array}$ & Different methods & Bagby et al. 2003 \\
\hline Yield & & Ojha and Bhattarai 2003; Stockdale 2005 \\
\hline \multicolumn{3}{|l|}{ Water } \\
\hline $\begin{array}{l}\text { Estimation of total } \\
\text { evaporation }\end{array}$ & Remote sensing & Kongo et al. 2007 \\
\hline Fog capture & Fog capture & Becker et al. 2005 \\
\hline \multirow[t]{3}{*}{ Stream flow } & Stream flow velocity & $\begin{array}{l}\text { Evans et al. 2006; Asquith and Wunder 2008; Le } \\
\text { Tellier et al. } 2009\end{array}$ \\
\hline & Water depth measurements & Kongo et al. 2007; Asquith and Wunder 2008 \\
\hline & Rainfall measurements & Kongo et al. 2007; Asquith and Wunder 2008 \\
\hline \multirow[t]{2}{*}{ Water quality } & Macroinvertebrate & Anonymous \\
\hline & Different methods & Chapman 1992; Kongo et al. 2007 \\
\hline
\end{tabular}


Annex 1. Continued

\begin{tabular}{|c|c|c|}
\hline Type of measurement & Methods & Citation \\
\hline \multicolumn{3}{|l|}{ Social } \\
\hline Forest benefits & Village meetings, accounting charts & Cronkleton et al. 2007 \\
\hline Land tenure & $\begin{array}{l}\text { Participatory 3-Dimensional Modeling } \\
\text { (P3DM) }\end{array}$ & Anil 2004 \\
\hline $\begin{array}{l}\text { Social inclusion and } \\
\text { communication }\end{array}$ & $\begin{array}{l}\text { Village meetings, developing } \\
\text { communication channels, joint analysis }\end{array}$ & Kusumanto 2007 \\
\hline $\begin{array}{l}\text { Well being (natural, } \\
\text { economic, social, political) }\end{array}$ & Several monitoring tools & CIFOR 2007 \\
\hline \multirow{14}{*}{$\begin{array}{l}\text { Participatory tools for } \\
\text { decision making }\end{array}$} & 4R framework & Lynam et al. 2007; Evans et al. 2006 \\
\hline & Bayesian belief networks & Lynam et al. 2007 \\
\hline & Discourse-based valuation & Lynam et al. 2007; Wilson and Howarth 2002 \\
\hline & Focus group discussion & Lynam et al. 2007; Ojha et al. 2003 \\
\hline & Future scenarios & $\begin{array}{l}\text { Wollenberg et al. 2000; CIFOR 2007; Lynam et } \\
\text { al. } 2007\end{array}$ \\
\hline & Key informant & McDougall 2001; Lynam et al. 2007 \\
\hline & Pebble distribution method & Lynam et al. 2007; van der Meer et al. 2007 \\
\hline & Participatory mapping & Ojha and Bhattarai 2003; Lynam et al. 2007 \\
\hline & Participatory modeling & Topp-Jorgensen et al. 2005 \\
\hline & Scoring & Evans et al. 2006; Lynam et al. 2007 \\
\hline & Spidergrammes & Lynam et al. 2007 \\
\hline & System dynamic modeling & Lynam et al. 2007 \\
\hline & Venn diagrams & Hamilton et al. 2001; Lynam et al. 2007 \\
\hline & Who Counts matrix & $\begin{array}{l}\text { Colfer et al. 1999; Purnomo et al. 2005; Lynam } \\
\text { et al. } 2007\end{array}$ \\
\hline
\end{tabular}




\section{Annex 2. Guidance to measuring and other useful publications}

\section{Carbon}

\begin{tabular}{|c|c|c|c|}
\hline Topic & Publication title & Author and publication year & Source \\
\hline Carbon accounting & $\begin{array}{l}\text { Review of existing methods for } \\
\text { carbon accounting }\end{array}$ & Bird, D.N. 2010 & CIFOR Occasional Paper 54 \\
\hline \multirow[t]{4}{*}{ Carbon stock } & $\begin{array}{l}\text { Carbon Stock Estimation } \\
\text { by Forest Measurement } \\
\text { Contributing to Sustainable } \\
\text { Forest Management in } \\
\text { Cambodia. }\end{array}$ & Kiyono, Y. et al. 2011 & $\begin{array}{l}\text { JARQ - Japan Agricultural } \\
\text { Research Quarterly } \\
44(1): 81-92\end{array}$ \\
\hline & $\begin{array}{l}\text { Mapping and monitoring } \\
\text { carbon stocks with satellite } \\
\text { observations: a comparison of } \\
\text { methods. }\end{array}$ & Goetz, S.J. et al. 2009 & $\begin{array}{l}\text { Carbon Balance and } \\
\text { Management 4(2): } \\
\text { doi:10.1186/1750-0680-4-2 }\end{array}$ \\
\hline & $\begin{array}{l}\text { Designing systems to monitor } \\
\text { carbon stocks in forests and } \\
\text { shrublands }\end{array}$ & Coomes, D.A. et al. 2002 & $\begin{array}{l}\text { Forest Ecology \& } \\
\text { Management 164(1-3):89- } \\
108 .\end{array}$ \\
\hline & $\begin{array}{l}\text { Measuring Carbon Stocks } \\
\text { Across Land Use Systems: A } \\
\text { Manual. }\end{array}$ & Hairiah, K. et al. 2011 & $\begin{array}{l}\text { http://www. } \\
\text { worldagroforestry.org/sea/ } \\
\text { Publications/files/manual/ } \\
\text { MN0050-11/MN0050-11-1. } \\
\text { PDF }\end{array}$ \\
\hline \multirow[t]{4}{*}{$\begin{array}{l}\text { Community carbon } \\
\text { measurement }\end{array}$} & $\begin{array}{l}\text { Community measurement of } \\
\text { carbon stock change for REDD }\end{array}$ & Skutch, M. et al. 2009 & FAO, Rome, Italy \\
\hline & $\begin{array}{l}\text { Forest Carbon Stock } \\
\text { Measurement: Guidelines for } \\
\text { measuring carbon stocks in } \\
\text { community-managed forests. } \\
\text { 2nd edition. }\end{array}$ & Subedi, B.P. et al. 2011 & $\begin{array}{l}\text { ANSAB, FECOFUN, ICIMOD } \\
\text { and NORAD }\end{array}$ \\
\hline & $\begin{array}{l}\text { Technical Manual for } \\
\text { Participatory Carbon } \\
\text { Monitoring. }\end{array}$ & Huy, B. 2011 & $\begin{array}{l}\text { UN-REDD Vietnam } \\
\text { Programme }\end{array}$ \\
\hline & $\begin{array}{l}\text { The value and the feasibility } \\
\text { of community monitoring of } \\
\text { biomass under REDD+. }\end{array}$ & Skutsch, M.M. et al. 2010 & $\begin{array}{l}\text { http://www. } \\
\text { communitycarbonforestry. } \\
\text { org/NewPublications/ } \\
\text { CIFOR\%20paper\%20 } \\
\text { Nov\%205\%20version.pdf }\end{array}$ \\
\hline \multirow[t]{2}{*}{ Forest degradation } & $\begin{array}{l}\text { Measuring and monitoring } \\
\text { forest degradation for REDD: } \\
\text { Implications of country } \\
\text { circumstances }\end{array}$ & Murdiyarso, D. et al. 2008 & $\begin{array}{l}\text { In Implications of country } \\
\text { circumstances. CIFOR, } \\
\text { Bogor, Indonesia }\end{array}$ \\
\hline & $\begin{array}{l}\text { Options for monitoring } \\
\text { and estimating historical } \\
\text { carbon emissions from forest } \\
\text { degradation in the context of } \\
\text { REDD+." }\end{array}$ & Herold, M. et al. 2011 & $\begin{array}{l}\text { Carbon Balance } \\
\text { and Management } \\
\text { 6(13):doi:10.1186/1750- } \\
\text { 0680-6-13 }\end{array}$ \\
\hline Overview of methods & $\begin{array}{l}\text { Monitoring forest emissions: a } \\
\text { review of methods. }\end{array}$ & Wertz-Kanounnikoff, S. 2008 & $\begin{array}{l}\text { In A review of methods. } \\
\text { CIFOR, Bogor, Indonesia }\end{array}$ \\
\hline $\begin{array}{l}\text { Social impacts of } \\
\text { carbon projects }\end{array}$ & $\begin{array}{l}\text { Manual for Social Impact } \\
\text { Assessment of Land-Based } \\
\text { Carbon Projects. }\end{array}$ & Richards, M., Panfil, S.N. 2010 & $\begin{array}{l}\text { Forest Trends, CCBA, } \\
\text { Rainforest Alliance and } \\
\text { Fauna \& Flora International }\end{array}$ \\
\hline
\end{tabular}




\section{VCS methodologies for different forest carbon contexts}

- VM0003: Methodology for improved forest management through extension of rotation age

- VM0005: Methodology for conversion of low-productive forest to high-productive forest

- VM0007: REDD methodology modules (REDD-MF)

- VM0009: Methodology for avoided mosaic deforestation of tropical forests

- VM0010: Methodology for improved forest management: conversion from logged to protected forest

- M0011: Methodology for calculating GHG benefits from preventing planned degradation

- VM0012: Improved forest management on privately-owned properties in temperate and boreal forests (LtPF)

- VM0015: Methodology for avoided unplanned deforestation

- VM0017: Adoption of sustainable agricultural land management

\section{Water services from forests}

\begin{tabular}{|c|c|c|c|}
\hline Topic & Publication title & Author and publication year & Source \\
\hline \multirow[t]{3}{*}{ Negotiating PES } & $\begin{array}{l}\text { Negotiating watershed } \\
\text { services. }\end{array}$ & Hope, R.A. et al. 2007 & IIED, London, UK \\
\hline & $\begin{array}{l}\text { Fair deals for watershed } \\
\text { services in Bolivia. }\end{array}$ & $\begin{array}{l}\text { Asquith, N. and Vargas, M.T. } \\
2007\end{array}$ & $\begin{array}{l}\text { Natural Resource Issues } \\
\text { No. 7, IIED, London, UK }\end{array}$ \\
\hline & $\begin{array}{l}\text { A GIS cost-benefit analysis- } \\
\text { based methodology to } \\
\text { establish a payment for } \\
\text { environmental services } \\
\text { system in watersheds: } \\
\text { application to the Calan } \\
\text { River in Honduras. }\end{array}$ & de Anguita, P.M. et al. 2011 & $\begin{array}{l}\text { Journal of Sustainable } \\
\text { Forestry } 30(1-2): 79-110\end{array}$ \\
\hline $\begin{array}{l}\text { Rapid hydrological } \\
\text { appraisal }\end{array}$ & $\begin{array}{l}\text { Rapid hydrological } \\
\text { appraisal in the context } \\
\text { of environmental service } \\
\text { rewards. }\end{array}$ & Jeanes, K. et al. 2006 & ICRAF, SEA Regional Office \\
\hline Stream flow & $\begin{array}{l}\text { Attempts to determine } \\
\text { the effects of forest cover } \\
\text { on stream flow by direct } \\
\text { hydrological measurements } \\
\text { in Los Negros, Bolivia. }\end{array}$ & Le Tellier, V. et al. 2009 & $\begin{array}{l}\text { Forest Ecology and } \\
\text { Management 258: } \\
\text { 1881-1888 }\end{array}$ \\
\hline \multirow[t]{2}{*}{ Water pricing } & $\begin{array}{l}\text { Pay - establishing payments } \\
\text { for watershed services. }\end{array}$ & Smith, M. et al. 2006 & IUCN, Gland, Switzerland \\
\hline & $\begin{array}{l}\text { Estimating a socially } \\
\text { optimal water price } \\
\text { for irrigation versus an } \\
\text { environmentally optimal } \\
\text { water price through } \\
\text { the use of geographical } \\
\text { information systems and } \\
\text { social accounting matrices. }\end{array}$ & Castellano, E. et al. 2008 & $\begin{array}{l}\text { Environmental \& Resource } \\
\text { Economics 39(3): 331-356 }\end{array}$ \\
\hline
\end{tabular}


Water services from forests. Continued

\begin{tabular}{llll}
\hline Topic & Publication title & Author and publication year & Source \\
\hline Water quality & $\begin{array}{l}\text { Water quality monitoring: } \\
\text { A practical guide to the } \\
\text { design and implementation } \\
\text { of freshwater quality } \\
\text { studies and monitoring } \\
\text { programmes. }\end{array}$ & $\begin{array}{l}\text { Bartram, J. and Ballance, R. } \\
1996\end{array}$ & WHO and UNEP \\
& $\begin{array}{l}\text { Water quality assessments } \\
\text { - a guide to use of biota, } \\
\text { sediments and water in } \\
\text { environmental monitoring - } \\
\text { second edition. }\end{array}$ & WHO, UNESCO and UNEP \\
& $\begin{array}{l}\text { Practical manual. Water } \\
\text { quality assessment: } \\
\text { macroinvertebrates as }\end{array}$ & Available in the internet. \\
biomonitoring indicator. & & If not, copies can be \\
provided by the authors.
\end{tabular}

\section{IUCN toolkits for valuing and trading water services}

The IUCN has published a range of technical guidance documents for valuing and trading water services through the Water and Nature Initiative (WANI). Under this number of toolkits for different aspects of water trading (see: http://iucn.org/about/work/programmes/water/resources/toolkits/):

- Change: Adaptation of water resources management to climate change

- Flow:The essentials of environmental flows

- Negotiate: Reaching agreements over water

- Pay: Establishing payments for watershed services

- Rule: Reforming water governance

- Share: Managing waters across boundaries

- Value: Counting ecosystems as water infrastructure

\section{Non-Timber Forest Products}

\begin{tabular}{|c|c|c|c|}
\hline Topic & Publication title & Author and publication year & Source \\
\hline \multirow[t]{2}{*}{ Management of NTFPs } & $\begin{array}{l}\text { Tapping the green } \\
\text { market: certification and } \\
\text { management of non- } \\
\text { timber forest products. }\end{array}$ & Guillen, A. et al. 2002 & Earthscan \\
\hline & $\begin{array}{l}\text { Beyond timber: certification } \\
\text { and management of non- } \\
\text { timber forest products. }\end{array}$ & Shanley, P. et al. 2008 & CIFOR, Bogor, Indonesia \\
\hline $\begin{array}{l}\text { Monitoring requirements } \\
\text { of FSC product } \\
\text { classification }\end{array}$ & $\begin{array}{l}\text { Non-timber forest products } \\
\text { certification standards } \\
\text { addendum. }\end{array}$ & & Smartwood \\
\hline NTFP commercialization & $\begin{array}{l}\text { Practical tools for } \\
\text { researching successful } \\
\text { NTFP commercialization: a } \\
\text { methods manual. }\end{array}$ & Marshall, E. et al. 2006 & CEPFOR \\
\hline
\end{tabular}


Non-Timber Forest Products. Continued

\begin{tabular}{|c|c|c|c|}
\hline Topic & Publication title & Author and publication year & Source \\
\hline Resource assessment & $\begin{array}{l}\text { Resource assessment of } \\
\text { non-wood forest products. }\end{array}$ & Wong, J.LG. et al. 2001 & FAO, Rome, Italy \\
\hline $\begin{array}{l}\text { Sustainable harvesting } \\
\text { levels }\end{array}$ & $\begin{array}{l}\text { Sustainable harvesting of } \\
\text { NTFPs: a community- based } \\
\text { methodology. }\end{array}$ & & $\begin{array}{l}\text { Environmental Change } \\
\text { Institute }(\mathrm{ECl}) \text {, the } \\
\text { Foundation for the } \\
\text { Revitalisation of Local } \\
\text { Health Traditions (FRLHT), } \\
\text { ForestAction }\end{array}$ \\
\hline
\end{tabular}

\section{Biodiversity}

\begin{tabular}{|c|c|c|c|}
\hline Topic & Publication title & Author and publication year & Source \\
\hline $\begin{array}{l}\text { Designing monitoring } \\
\text { programme }\end{array}$ & $\begin{array}{l}\text { The challenge of } \\
\text { monitoring biodiversity in } \\
\text { payment for environmental } \\
\text { service interventions. }\end{array}$ & Sommerville, M.M. et al. 2011 & $\begin{array}{l}\text { Biological Conservation } \\
\text { Restoration and } \\
\text { Sustainability } 144 \\
\text { (12):2832-41. }\end{array}$ \\
\hline \multirow[t]{2}{*}{$\begin{array}{l}\text { High Conservation Value } \\
\text { Forest }\end{array}$} & $\begin{array}{l}\text { Mapping high conservation } \\
\text { values at large scales } \\
\text { for effective site-level } \\
\text { management }\end{array}$ & $\begin{array}{l}\text { Stewart, C. and Rayden, T. } \\
2009\end{array}$ & $\begin{array}{l}\text { HCV Resource Network and } \\
\text { ProForest }\end{array}$ \\
\hline & $\begin{array}{l}\text { Assessment, management } \\
\text { and monitoring of High } \\
\text { Conservation Value Forest } \\
\text { (HCVF). A practical guide } \\
\text { for forest managers. }\end{array}$ & Rayden, T. 2008 & ProForest, Oxford, UK \\
\hline
\end{tabular}

\section{The Global HCVF Toolkit}

The Global HCVF Toolkit consists of three parts:

Part 1: Introduction. This gives a general introduction to the concept of HCVF and how different users can apply it.

Part 2: Defining High Conservation Value Forests at a national level. The ideal way of implementing the concept is by developing national (or sub-national) interpretations that clearly define the local HCVs. This part of the Toolkit provides a practical methodology to be used at a national (or sub-national) level for defining High Conservation Values.

Part 3: Identifying and Managing High Conservation Value Forests: A guide for forest managers. This part of the Toolkit is aimed at forest managers, other land managers, investors, donors and conservation practitioners who wish to implement HCVF as part of best management practice.

There are also various national-level toolkits of direct relevance to the identification, monitoring and management of biodiversity in the ForCES pilot sites: Chile, Vietnam and Indonesia. 


\section{Modeling tools and software programs}

A range of modelling tools and software programs have been developed to assist the mapping of multiple ecosystem services in project sites or at the larger landscape level. We summarize a few.

\begin{tabular}{ll}
\hline Tool & What is it about \\
\hline $\begin{array}{l}\text { Fog Interception for the } \\
\text { Enhancement of Streamflow } \\
\text { in Tropical Areas (FIESTA) }\end{array}$ & $\begin{array}{l}\text { FIESTA is a spatially detailed decision-support } \\
\text { tool for managing land-use and climate-change } \\
\text { impacts on water. It helps guide decisions on } \\
\text { where to develop watershed service projects, } \\
\text { although it is not yet a stage in which the tool can } \\
\text { be used for actual valuation of water. }\end{array}$ \\
$\begin{array}{l}\text { Integrated Valuation of } \\
\text { Invironmental Services and is a family of tools to map and value the } \\
\text { Tradeoffs (InVEST) }\end{array}$ & $\begin{array}{l}\text { goods and services from nature that are essential } \\
\text { for sustaining and fulfilling human life. InVEST } \\
\text { enables decision makers to assess the tradeoffs } \\
\text { associated with alternative choices and to identify } \\
\text { areas where investment in natural capital can } \\
\text { enhance human development and conservation in } \\
\text { terrestrial, freshwater and marine ecosystems. }\end{array}$
\end{tabular}

Social Values for Ecosystem Services (SoIVES)

Soil and Water Assessment Tool

The ARtifical Intelligence for Ecosystem Services (ARIES)
SolVES can be used to assess, map and quantify the perceived social values of ecosystem services. SoIVES derives a quantitative social values metric, the Value Index, from a combination of spatial and nonspatial responses to public attitude and preference surveys. The Value Index provides a basis of comparison within and among survey subgroups to consider the effect of social contexts on the valuation of ecosystem services.

SWAT is a river-basin scale model developed to quantify the impact of land-management practices in large, complex watersheds.

ARIES tool is a web-based technology intended to assist rapid ecosystem services (ES) assessment and valuation using an artificial intelligence approach. It determines optimisation of PES, assesses funding mechanisms and assists with conservation planning and forecasting change in ES provision. Via GIS data, ARIES can both produce models or use GIS input. ARIES also produces maps and quantitative data about ecosystem services.

\section{Source}

http://www.falw.vu/ fiesta/

http://www.naturalcapitalproject. org/InVEST.html

http://solves.cr.usgs.gov/

http://swatmodel.tamu.edu/

http://www.ariesonline.org/ 


\section{Glossary}

\author{
Additionality
}

Afforestation

Baseline

Biochemical oxygen demand (BOD)

Biomass

Carbon pool

Carbon stock

Compliance monitoring indicator

Conductivity

Deforestation

Degradation

Dissolved oxygen

Flow discharge

Impact indicator

Leakage

Non-timber forest products
Actual or prevented changes in the quality and quantity of ecosystem services compared to a business-as-usual scenario.

The direct human-induced conversion of non-forest land that was never forested to permanent forested land.

The benchmark on which the payments for ecosystem services are based on.

BOD measures the amount of oxygen consumed by microorganisms in decomposing organic matter in stream water. BOD also measures the chemical oxidation of inorganic matter.

The total dry mass of living organic material.

A reservoir or stock that can accumulate or release carbon. In forests there are five main carbon pools: aboveground biomass, belowground biomass, dead wood, litter and soil organic matter.

The quantity of carbon contained in a carbon pool.

An indicator that ensures that management practices do not cause negative impacts.

Total amount of dissolved ions in water.

The long-term or permanent conversion of land from forest to nonforest.

Changes within the forest that negatively affect the structure or function of the forest.

The amount of oxygen in the water.

Also known as the stream flow, discharge is the volume rate of the water flow.

Environmental impact indicator measures the impact of management practices on the provision of ecosystem services. Social impact indicator measures the effects of the ecosystem services scheme on the livelihoods of affected people.

The extent to which payments for ecosystem services would displace detrimental activities to other locations.

Non-timber forest products (NTFPs) are products of biological origin other than timber derived from forests, other wooded land and trees outside forests. 
Permanence

Reforestation

Total dissolved solids

Total suspended solids

Turbidity
The duration and non-reversibility of a provision of ecosystem services.

Under the Kyoto Protocol, reforestation is "the direct human-induced conversion of non-forested land to forested land through planting, seeding and/or the human-induced promotion of natural seed sources, on land that was forested but that has been converted to nonforested land."

Refers to any minerals, salts, metals, cations or anions dissolved in water.

Refers to the amount of silt and clay particles, plankton, algae, fine organic debris and other particulate matter that will not pass through a filter in water.

The clarity of the water. 
CIFOR Working Papers contain preliminary or advance research results on tropical forest issues that need to be published in a timely manner to inform and promote discussion. This content has been internally reviewed but has not undergone external peer review.

Ecosystem services and goods are the multiple benefits people obtain from ecosystems. The benefits provided by forests include carbon sequestration, prevention of erosion, flood control, and water purification as well as aesthetic beauty. Although humans are fundamentally dependent on these services, they also pose threat to the services through their activities such as deforestation and water pollution.

One potential way to improve forest management is the emerging certification of ecosystem services. Either the forest management (including the ecosystem services provided by the forest) or the provision of the ecosystem services could be certified. Regardless of the approach chosen monitoring is required as it provides evidence to buyers that certified goods and services are indeed obtained from forests managed according to agreed standards. Furthermore, monitoring helps to assess whether certain strategies are effective and efficient in achieving the management objectives. However, building effective monitoring programs is challenging: Many forest managers recognize the need to monitor, but are unclear about the best approach: what to measure and how to measure it.

This working paper provides the groundwork for the development of compliance and impact monitoring indicators and building monitoring programmes. It introduces certification and discusses the implications of certification of ecosystem services for measuring and monitoring. It provides an overview of different types of monitoring and possible impact indicators and their measurement. Finally, it addresses compliance monitoring indicators in the context of existing Forest Stewardship Council certification standards.

RESEARCH PROGRAM ON

Forests, Trees and Agroforestry
This research was carried out by CIFOR as part of the CGIAR Research Program on Forests, Trees and Agroforestry (CRP-FTA). This collaborative program aims to enhance the management and use of forests, agroforestry and tree genetic resources across the landscape from forests to farms. CIFOR leads CRP-FTA in partnership with Bioversity International, CATIE, CIRAD, the International Center for Tropical Agriculture and the World Agroforestry Centre.
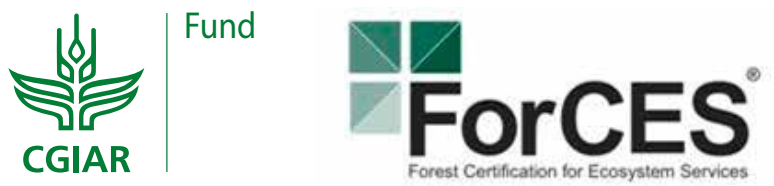